University of Chicago Law School

Chicago Unbound

Public Law and Legal Theory Working Papers

Working Papers

2007

\title{
Can the Income Tax Be Saved? The Promise and Pitfalls of Unitary Formulary Apportionment
}

Julie Roin

Follow this and additional works at: https://chicagounbound.uchicago.edu/public_law_and_legal_theory

Part of the Law Commons

Chicago Unbound includes both works in progress and final versions of articles. Please be aware that a more recent version of this article may be available on Chicago Unbound, SSRN or elsewhere.

\section{Recommended Citation}

Julie Roin, "Can the Income Tax Be Saved? The Promise and Pitfalls of Unitary Formulary Apportionment" (University of Chicago Public Law \& Legal Theory Working Paper No. 170, 2007).

This Working Paper is brought to you for free and open access by the Working Papers at Chicago Unbound. It has been accepted for inclusion in Public Law and Legal Theory Working Papers by an authorized administrator of Chicago Unbound. For more information, please contact unbound@law.uchicago.edu. 


\title{
CHICAGO
}

Public LAW AND LegAL THEORY WORKING PAPER NO. 170

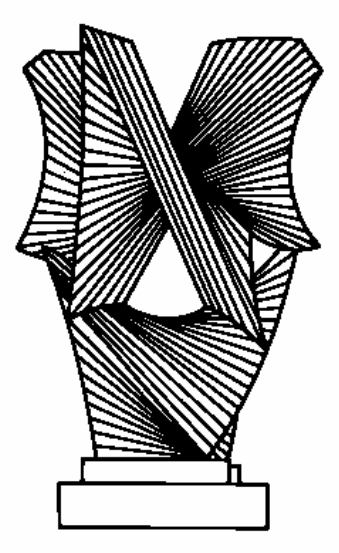

\section{CAN THE INCOME TAX BE SAVED? THE PROMISE AND PITFALlS OF UNITARY FORMULARY APPORTIONMENT}

\author{
Julie Roin \\ THE LAW SCHOOL \\ THE UNIVERSITY OF CHICAGO
}

April 2007

This paper can be downloaded without charge at the Public Law and Legal Theory Working Paper Series: http://www.law.uchicago.edu/academics/publiclaw/index.html and The Social Science Research Network Electronic Paper Collection:

http://ssrn.com/abstract_id=984076 


\section{Can The Income Tax Be Saved?: The Promise and Pitfalls of Adopting Unitary Formulary Apportionment Julie Roin*}

$\underline{\text { Abstract }}$

Governments must raise revenue to provide the services desired by their constituents. Most developed nations raise a substantial portion of the necessary revenues through the imposition of corporate and individual income taxes. But recent economic developments, and particularly the increasing globalization of capital markets, has made enforcement of national income taxes increasingly difficult. The enforcement issues go beyond mere tax competition; nations are finding it difficult to collect taxes on income that could not be earned anywhere other than within their borders. A primary cause of these difficulties lies in countries' failure to devise effective methods of taxing the domestic income of foreign corporations. All too often, such income ends up taxed nowhere. Not surprisingly and all too successfully, taxpayers strive to arrange their affairs so that their income becomes such nowhere income. It is hard to see how the corporate, and perhaps even the individual income tax can survive as an effective revenue raising device unless and until countries devise an effective method of taxing the domestic income of foreign corporations.

One component of many of these tax reduction schemes is the manipulation of "transfer prices," or the prices charged by one corporation for the provision of goods or services to another, related corporation. By setting such prices unduly high or low, taxpayers can change the source or character of income as well as the identity of the earning taxpayer. Although on paper, almost all tax authorities have the right to adjust transfer prices to accord with “arm's length” prices, this has proven exceptionally difficult to do in real world situations. In addition, even accurate pricing often fails solve the problem posed by the nontaxation of foreign corporate earners because taxpayers have learned to manipulate economically meaningless source rules to locate income in low tax jurisdictions. Increasingly, academics and EU bureaucrats have come to believe that the solution to the problem of nontaxation of international income lies in replacing the current arm's length, separate entity based taxing regimes, which rely on transfer prices and source rules to determine the amount of income earned by and taxed in the hands of domestic operating entities, with unitary formulary taxing regimes similar to those used by some states of the United States. Such unitary formulary regimes would use mathematical formulas based on "real economic factors" to divide income among members of economically integrated corporate groups and the countries in which they operate.

The paper examines the prospects for success of formulary taxing regimes by looking at the experiences of the states of the United States, which have operated such regimes. It concludes that switching to a formulary regime will not solve most of the

\footnotetext{
* Seymour Logan Professor of Law, University of Chicago Law School. I am indebted to participants in workshops at the University of Chicago Law School and the University of Toronto Law Faculty for their comments on earlier drafts. Mistakes remain my own. Not for quotation or attribution without the author's permission. Comments welcome. Email: julie_roin@law.uchicago.edu.
} 
problems afflicting the current, arm's length based system, and further, that taxpayers will expand the use techniques developed to avoid the reach of the subpart $F$ regime to undercut the unitary nature of any new formulary regime.

\section{$\underline{\text { Introduction }}$}

Governments must raise revenue to provide the services desired by their constituents. Most developed nations raise a substantial portion of the necessary revenues through the imposition of corporate and individual income taxes. ${ }^{1}$ But recent economic developments, and particularly the increasing globalization of capital markets, has made enforcement of national income taxes increasingly difficult. These enforcement issues go beyond mere tax competition; ${ }^{2}$ nations are finding it difficult to collect taxes on income that could not be earned anywhere other than within their borders. ${ }^{3}$ A primary cause of these difficulties lies in countries' failure to devise effective methods of taxing the domestic income of foreign corporations. All too often, such income ends up taxed nowhere.

It is hard to see how the corporate, and perhaps even the individual income tax can survive as an effective revenue raising device unless and until countries devise an effective method of taxing the domestic income of foreign corporations. The failure to tax the domestic income of foreign corporations undercuts countries' ability to tax domestic corporations and individuals in two different ways. First, it is politically difficult and perhaps economically self destructive to tax domestic corporations on their domestic income at rates substantially higher than those faced by foreign competitors engaged in similar activities in the same country. When countries succeed in collecting such taxes, domestic corporations are at an economic disadvantage relative to those competitors, offering investors lower returns, having less capital for expansion, and having less room

\footnotetext{
${ }^{1}$ Although wage taxes (such as social security taxes) and value added taxes (outside the United States) are also very significant sources of revenue, see Reuven S. Avi-Yonah, Globalization, Tax Competition, and the Fiscal Crisis of the Welfare State, 113 HARV. L. REV. 1573, 1621 (2000); William B. Barker, Optimal International Taxation and Tax Competition: Overcoming the Contradictions, 22 Nw. J. INT'L L. \& Bus. 161, 166 (2002), personal and corporate income taxes remain important revenue sources. See id., at 166.

${ }^{2}$ Tax competition is just part of a larger competition for "mobile capital." Because countries gain any time they attract investment generating local benefits in excess of local costs, they may "bid" for such investments by reducing taxes, providing subsidies, or decreasing regulatory burdens. See Julie Roin, Competition and Evasion: Another Perspective on International Tax Competition, 89 GEO. L. J. 543, 560 (2001). Though such bidding, like all price competitions, can have beneficial allocative effects, such competition can also be a source of concern for those who worry that the governments doing the bidding will mistake the costs and benefits (or the mobility) of the investments at issue or the ability of governments to raise sufficient funds from other sources. See id. at 562. Others worry that much competition takes place between similarly situated countries, resulting in (from the governments' perspective) a prisoner's dilemma and a reallocation of locational rents from governments and nonmobile taxpayers to owners of mobile capital. See Reuven S. Avi-Yonah, supra note 1, at 1583.

${ }^{3}$ For example, while manufacturing activities and their accompanying income often can be moved to other jurisdictions, the same cannot be said of sales made to residents of a jurisdiction. Yet profitable companies with considerable U.S. sales activities often pay relatively little U.S. tax. See infra Part II (outlining tax avoidance devices).
} 
for price concessions. ${ }^{4}$ But countries rarely succeed in collecting such taxes for long because domestic corporations - and domestic investors--learn to use tax favored foreign corporations to avoid domestic taxation. This is the second way the undertaxation of foreign corporations undercuts countries' ability to levy an income tax, by encouraging and facilitating tax avoidance. Taxpayers divert income away from domestic corporations and into related foreign corporations; or they transform domestic corporations into foreign corporations through recapitalizations, reorganizations or mergers with foreign corporations. Investors cease creating and investing in domestic entities, choosing instead to utilize foreign entities. When foreign corporations can reap the benefits of operating in and selling to customers located in high tax jurisdictions without payment of substantial income taxes, over time one should expect virtually all domestic investments in high tax countries to be made through such tax favored foreign corporations.

Even with political will, ${ }^{5}$ high tax countries face significant practical impediments in taxing such income. One component of many of the current tax reduction schemes is the manipulation of "transfer prices," or the prices charged by one corporation for the provision of goods or services to another, related corporation. By setting such prices unduly high or low, taxpayers can change the source or character of income as well as the identity of the earning taxpayer. Although on paper, almost all tax authorities have the right to adjust transfer prices to accord with “arm's length” prices, this has proven exceptionally difficult to do in real world situations. In addition, even accurate pricing often fails solve the problem posed by the nontaxation of foreign corporate earners because of weaknesses in the rules determining the source of income. Increasingly, academics $^{6}$ and EU bureaucrats ${ }^{7}$ have come to believe that the solution to the problem of

\footnotetext{
${ }^{4}$ Whether foreign corporations would utilize their tax advantages for competitive reasons is unclear. They may prefer simply to enjoy their higher after-tax return and distribute higher dividends. See Michael S. Knoll, Taxes and Competitiveness, University of Pennsylvania Institute for Law and Econ. Research Paper No. 06-28, pp. 33-34 (2006), http://ssrn.com/abstract=953074 .

${ }^{5}$ Serious question exists as to whether high tax countries actually want to impose taxes on foreign investors, including foreign businesses. Though such taxation is at least superficially popular, some fear that taxation will drive foreign investors and investment to lower tax jurisdictions. This fear of driving away foreign investment was among the justifications for removing the withholding tax from portfolio interest income in the U.S. in 1984, and remains a concern in many other countries. See STAFF OF THE Joint Committee on TAXAtion, General Explanation of THE REVEnUE PROVisions of the TAX REFORM ACT OF 1984391 ("Congress believed it important that U.S. businesses have access to the Eurobond market as a source of capital”); Suzanne Walsh, Taxation of Cross-Border Interest Flows: The Promises and Failures of the European Union Approach, 37 GEO. WASH. INT'L L. REV. 251, 251-252 (2005) ("Wealthier, industrialized countries...hesitate to abandon advantageous tax practices, particularly bank secrecy, that protect their capital markets and financial sectors"). Of course, foreign investment in one country could be domestic investment in another country; to a large extent the favorable tax treatment of "foreign investment" merely encourages investors to invest in any country other than their own. The favorable treatment of foreign investment thus can be viewed as an example of a classic prisoners' dilemma. Alternatively, conspiracy theorists may analyze the situation in principal-agent terms: the political class has been using obscure tax rules to lower the effective rate of tax on their patrons, the largest companies and wealthiest taxpayers. I have no interest in arguing as to which of these two (or some other) characterizations is more "correct”; this article is instead oriented towards the question of whether a different outcome is possible if the affected polities desire one.

${ }^{6}$ See, e.g., JOANN MARTENS-WEINER, COMPANY TAX REFORM IN THE EUROPEAN UNION: GUIDANCE FROM THE UNITED STATES AND CANADA ON IMPLEMENTING FORMULARY APPORTIONMENT IN THE EU (Springer 2006), at 9 (“From a tax administration point of view, although it may not guarantee a 'correct' profit
} 
nontaxation of international income lies in replacing the current arm's length, separate entity based taxing regimes, which rely on transfer prices to determine the amount of income earned by and taxed in the hands of domestic operating entities, with unitary formulary taxing regimes similar to those used by some states of the United States. These unitary formulary regimes use mathematical formulas based on "real economic factors" to divide income among members of economically integrated corporate groups. Essentially, such methods disregard the separate existence of related corporate entities, allocating their collective income among affected countries based on each country's relative contribution of identifiable economic factors. States in the United States use formulary methods to apportion the income derived from multistate enterprises; ${ }^{8}$ their

allocation in the traditional sense, formulary apportionment appears better suited to avoid double taxation problems in the EU than the arm's length transfer pricing system.”); Reuven Avi-Yonah, A Proposal to Adopt Formulary Apportionment For Corporate Income Taxation, ("Under our proposal, the U.S. tax base for multinational corporations would be calculated based on a fraction of their worldwide income. This fraction would simply be the share of their worldwide sales that occur in the United States."); Reuven Avi-Yonah, The Rise and Fall of Arm's Length: A Study in the Evolution of U.S. International Taxation, 15 VA. TAx REv. 89, 159 (1995) ("The next step is for the United States to propose discussions on the adoption of formulary techniques along the lines suggested above.”); R.M. Bird and D.J.S. Brean, The Interjurisdictional Allocation of Income and the Unitary Taxation Debate, 34 CAN. TAX J. 1377, 1412 (1986) ("While the accepted international approach has the considerable political advantage of (apparently) not requiring formal agreement on the division of the tax base, it is not clear that this arrangement will long endure"); Marcel Gerard, Reforming the Taxation of Multijurisdictional Enterprises in Europe, A Tentative Appraisal, CESifo Working Paper No. 1795, http://www.SSRN.com/abstract=935009 (2006); Walter Hellerstein and Charles E. McClure, Jr., The European Commission's Report on Company Income Taxation: What the EU Can Learn from the Experience of the US States, 11 INT'L TAX \& PUB. FIN. 199, 218 (2004), Paul McDaniel, Formulary Taxation in the North American Free Trade Zone, 49 TAX. L. REV. 691,738 (1994); Charles E. McLure, Jr., Replacing Separate Entity Accounting and the Arm's Length Principle with Formulary Apportionment, 56 BULL. FOR INT’L FISCAL Doc. 586, 599 (2002).

${ }^{7}$ In 2001 and again in 2003, the European Commission proposed replacing the current rules for the taxation of EU source income of multinational companies with a formulary system operating on a commonly defined, consolidated income base. See European Commission, An Internal Market without Company Tax Obstacles, Achievements, Ongoing Initiatives and Remaining Challenges, COM(2003)726 final; European Commission, Towards an Internal Market Without Tax Obstacles-A Strategy for Providing Companies With a Consolidated Corporate Tax Base for their EU-wide Activities: Communication from the Commission to the Council, the European Parliament and the Economic and Social Committee , COM(2001)582 final. Though the European Commission's enthusiasm for moving away from the current practice of relying on arm's length pricing standards and separate entity accounting was not initially shared by many member governments, decisions by the European Court of Justice striking down critical parts of national tax regimes as "discriminatory" or otherwise in violation of terms of the Treaty of Rome have led some commentators to conclude that some sort of EU wide formulary tax system is inevitable. See Joe Kirwin, ECJ's Advocate General Rejects U.K. Denial of Subsidiary Losses, 67 DAILY TAX REP'T G-4, G-5 (2005) (EU commission official stated "We have been warning member states for some years that it was crucial to move towards harmonizing various aspects of corporate taxation laws... We have indicated that if this did not happen through legislation it would happen through court rulings.”); Bengt Ljung, EU's Kovacs Urges U.K. to Agree on Corporate Tax Harmonization, 118 DAILY TAX REP'T G-7, G-8 (2005) (“At the European Parliament, the tax commissioner claimed an increasing number of member states are supporting a harmonization of the company tax base. Of the 25 countries, 'maybe five' are still reluctant”); Lee A. Sheppard, Dowdy Retailer Set to Destroy European Corporate Tax, Part 2, 38 TAX NOTES INT’L 627, 632633 (2005) ("This case is a fork in the road for the corporate income tax. The choices are repeal of the corporate income tax, with or without replacement, or mandatory worldwide combination of all controlled entities.").

${ }^{8}$ Such methods are also used to allocate corporate income among the Canadian provinces, see JoANN MARTENS-WEINER, supra note 6, at 2, and some European nations have also experimented with formulary 
methods allow each state to tax the percentage of the taxpayer's income corresponding to the proportion of that taxpayer's overall sales, payroll and property located within the state. The idea is to use the lessons of that (not altogether happy) experience to develop a version capable of dealing with multinational income to be implemented at the national (or international) level.

Replacing the current international tax rules with a system of unitary formulary taxation would entail tremendous institutional and transition costs in the U.S. and elsewhere. ${ }^{9}$ Further, maintaining the degree of legal uniformity necessary for such a system to operate to its full potential would have its own costs. ${ }^{10}$ Ultimately, the question is whether the gains likely to be generated from adoption of such a system would outweigh these costs. Skepticism is warranted because many of the avoidance techniques honed by use under the current tax rules will be just as effective at defeating attempts to tax under unitary formulary methods of taxation. Stated simply, many of the real economic factors are no more real, or less susceptible to manipulation, than the are the factors used to determine source of income under the current arm's length based system. Further, techniques honed by taxpayers to avoid the reach of the current subpart F rules will work to frustrate the intended purpose of moving from a separate entity to a unitary system for the taxation of groups of related corporations. Thus, much potential tax revenue will likely continue to escape even from a carefully crafted and widely adopted unitary formulary tax system. This is not a conclusion I am happy to reach because it is not accompanied by any belief in the reparability of the current "system" for the taxation of income derived from international transactions. But it is a conclusion worth putting forward because it makes no sense to spend the time, effort and political goodwill necessary to put unitary formulary taxation into practice if it will not save the income tax.

This article is divided into four parts. Part I describes the current U.S. rules for the taxation of the domestic income of foreign taxpayers, including foreign corporations. Although these rules are unique in some respects, they are close enough to the tax rules prevailing in other jurisdictions to serve as a representative model of developed country regimes for the taxation of foreign investors. Part II explains the devices taxpayers have used to avoid taxation under those rules and the ineffectiveness of the current countermeasures taken by the government, or proposed by commentators, to stem this tax avoidance. Part III explores the operation of unitary, formulary tax systems and their weaknesses. Part IV concludes.

\section{Current U.S. Rules for the Taxation of Income from International Transactions}

The U.S., like most countries, asserts jurisdiction to tax based on both residence and source. U.S. persons, including U.S. corporations, are subject to tax on their worldwide income, while foreign persons are subject to U.S. tax on all income derived from sources within the U.S. However, this jurisdiction is not exercised to the maximum extent allowed. Taxation of much of the foreign sourced income earned by U.S.

taxation. See Lee A. Sheppard, supra note 7, at 632-634 (briefly describing limited experiments in Denmark, France, and Italy).

${ }^{9}$ See Julie Roin, Taxation Without Coordination, 31 J. OF LEGAL STUD. S61, S78-84 (2002) (detailing institutional impediments to development of a common income tax base).

${ }^{10}$ See Julie Roin, Can Income from Capital Be Taxed? An International Perspective, in TAXING CAPITAL INCOME (Brookings Institution, forthcoming 2007). 
taxpayers is deferred, ${ }^{11}$ while substantial amounts of the U.S. source income of foreign taxpayers is exempted from U.S. tax by statute ${ }^{12}$ or treaty. ${ }^{13}$ The critical dividing line in the case of foreign taxpayers is between business income and investment income. Business income is more likely to be taxed at source than investment income.

\section{A. The Taxation of Business Income}

Under statutory law, the U.S. taxes the income of a foreign taxpayer engaged in a U.S. trade or business as it does the income of a domestic taxpayer. ${ }^{14}$ All taxpayers are taxable on the net income generated by such business activities. Taxation thus turns on whether or not a foreign taxpayer's activities rise to the level of a "trade or business." However, when a taxpayer is a resident of a country with which the U.S. has a tax treaty, the predicate for taxation is somewhat higher; the taxpayer must have a "permanent establishment" in the U.S. before its business related income becomes taxable in the U.S. ${ }^{15}$ And even then, only the income "attributable" to that permanent establishment is so taxable. ${ }^{16}$ Though the exact contours of a permanent establishment can be uncertain, and moreover may vary from treaty to treaty, a taxpayer generally must have an office or other fixed place of business in which it engages in activities other than the purchase of goods. ${ }^{17}$ The taxpayer must engage in selling or manufacturing or other income producing activities at the location; then and only then does the income attributable to those activities become taxable in the U.S. ${ }^{18}$

\footnotetext{
${ }^{11}$ Technically, taxation is deferred when the U.S. taxpayer earns the foreign income indirectly, through an intermediate foreign corporation. The U.S. does not tax this foreign corporation because it is neither a resident of, nor earns income from, the United States. With some exceptions, the U.S. shareholder(s) of such foreign corporations, like shareholders of domestic corporations, do not have to include any portion of its income in their own incomes unless and until the foreign corporation distributes a dividend or the U.S. shareholder sells its shares in the foreign corporation.

12 The U.S. imposes a 30\% withholding tax on the gross amount of certain, limited categories of foreigners' investment income, see I.R.C. $\S \S 871(a), 881(a)$, and taxes any net income "effectively connected with the conduct of a trade or business within the United States.” I.R.C. §§ 871(b), 882(a). These statutory rules explicitly rule out the taxation at source of “portfolio interest income," interest paid by an unrelated U.S. debtor, see I.R.C. $\S \S 871(\mathrm{~h})$ \& 881(c), as well as any nonbusiness income falling outside the definition of “fixed, determinable, annual or periodical” income. See I.R.C. §§ 871(a)(1), 881(a)(1). The latter exclusion covers almost all nonbusiness gains from the sale of property, see Treas. Reg. $§ 1.871-7(a)(1)$, insurance premiums, and other income items with substantial associated costs. See Rev. Rul. 80-222, 1980-2 C.B. 211.

13 Tax treaties typically reduce or eliminate the withholding tax otherwise imposed on investment income, see Charles H. Gustafson, Robert J. Peroni, Richard Crawford Pugh, TAXation of InTERnational Transactions MATERIAls, TEXT AND PROBlEMs 209 (3d ed. 2006), while increasing the nexus requirement for the taxation of a foreigner's business income. Id. at 165.

${ }^{14}$ See I.R.C. $\S \S 871($ b) (imposing tax on effectively connected income “as provided in section 1 or 55”), 882(a) (imposing tax on effectively connected income “as provided in section 11, 55, 59A, or 1201(a)”).

${ }^{15}$ United States Model Income Tax Convention of November 15, 2006, Art. 7.1. This provision of the U.S. Model Treaty is identical to its counterpart in the OECD Model Treaty. See OECD Model Tax Convention on Income and on Capital, January 28, 2003, Art. 7.1.

${ }^{16}$ U.S. Model Treaty, supra, at Art. 7. 2; OECD Model Tax Convention, supra, at Art. 7.2.

${ }^{17}$ U.S. Model Treaty, supra, at Art. 5; United States Model Technical Explanation Accompanying the United States Model Income Tax Convention of November 15, 2006, at p. 15 ("the term means a fixed place of business through which the business of an enterprise is wholly or partly carried on”); OECD Model Tax Convention, supra, at Art. 5.

${ }^{18}$ Most treaties contain a long list of "preparatory" or "auxiliary” activities that a foreign taxpayer can carry out through a fixed place of business without causing that fixed place of business to be deemed a
} 
Since corporations, by definition, can only act through agents, an important question for the operation of these rules is the extent to which affiliates operating in the U.S. become mere agents of the (formally distinct) foreign corporations, so that the activities and offices of the U.S. entity can be imputed to the foreign corporation. Such imputation brings with it, of course, jurisdiction to tax the foreign entity which may itself have no other office or business dealings inside the U.S. Both the Internal Revenue Code $^{19}$ and treaties ${ }^{20}$ contain provisions which make it relatively easy for foreign corporations to treat even related U.S. corporations as nonagent, independent contractors, thus avoiding implication in those corporations' U.S. business activities. As a result, many foreign corporations can avoid U.S. taxation even on their U.S. sourced income and, assuming foreign, residence based taxes are lower than U.S. taxes on such income in the hands of the U.S. affiliates would have been, their owners have an economic incentive to shift income from the U.S. corporations to their foreign affiliates.

\section{B. The Taxation of Investment Income}

Under statutory law, the U.S. subjects some forms of investment income to a withholding tax equal to 30 percent of the gross income amount of such income, while other forms of investment income are exempt from tax. To some extent, this dichotomous treatment tracks administrative and fairness concerns. Most gains earned by nonbusiness taxpayers are exempted from source tax because the imposition of a tax based on gross sales receipts seems likely to lead to overtaxation, buyers are unlikely to know their sellers’ basis making withholding based on net income impossible ${ }^{21}$, and the

\footnotetext{
“permanent establishment.” See United States Model Income Tax Convention of November 15, 2006 , Art. 5. 4.

${ }^{19}$ See I.R.C. §864(c)(5) (agent's office or fixed place of business disregarded unless “such agent has the authority to negotiate and conclude contracts in the name of the nonresident alien individual or foreign corporation and regularly exercises that authority or has a stock of merchandise from which he regularly fills orders on behalf of such individual or foreign corporation, and (ii) is not a general commission agent, broker, or other agent of independent status acting in the ordinary course of his business”). Technically, this imputation rule applies only for purposes of determining whether the taxpayer has "an office or fixed place of business in the U.S." rather than whether the taxpayer has a "trade or business" in the U.S. However, a taxpayer engaged in a U.S. trade or business is only taxable in the U.S. on that business's "effectively connected income" and it is relatively simple for most taxpayers to avoid creating "effectively connected income" when they do not have an "office or fixed place of business."

${ }^{20}$ See United States Model Income Tax Convention of November 15, 2006, Art. 5.7 ("The fact that a company that is a resident of a Contracting State controls or is controlled by a company that is a resident of the other Contracting State, or that carries on business in that other State...shall not be taken into account in determining whether either company has a permanent establishment in that other State.”), Art. 5.5 (imputing permanent establishment only where a dependent agent "has and habitually exercises in a Contracting State an authority to conclude contracts that are binding on the enterprise”), and Art. 5.6 (disregarding permanent establishments of “a broker, general commission agent, or any other agent of an independent status, provided that such persons are acting in the ordinary course of their business as independent agents”). Again, these provisions are consistent with the provisions of the OECD model treaty. See OECD Model Tax Convention, Art. 5.5 - 5.7.

${ }^{21}$ Congress has provided an exception to this general rules of nontaxation for real estate gains. See I.R.C. $\S \S 897,1445$ (taxing real estate gains as trade or business income, but effectuating taxing scheme through withholding of portion of gross sales proceeds). Whether such a tax regime could be enforced in other contexts, with property subject to less formal transfer mechanisms and perhaps greater susceptibility to replacement by derivative contracts is unclear. Although many countries levy value added taxes on a border-adjustable basis, value added taxes are imposed on gross receipts, rather than being tied in any way
} 
obstacles to enforcement of a net income tax on nonresidents with limited contacts in the U.S. are substantial. ${ }^{22}$ But some of the exemptions stem from political decisions. "Portfolio interest income," that is, interest paid to taxpayers unrelated to the U.S. debtor, was exempted from the withholding tax in 1984 in order to encourage foreign investors to supply cheap capital to U.S. enterprises. ${ }^{23}$

Tax treaties further reduce source taxation of investment income, in many cases eliminating the withholding tax otherwise due on interest, royalties, and dividend income received by residents of the treaty partner. ${ }^{24}$ Since these treaties are reciprocal in form, in theory these treaty reductions merely substitute increases in residence taxation for decreases in source taxation; in actuality, as discussed in more detail below, often the result is no taxation of this income by any country. ${ }^{25}$

The analysis in this paper focuses largely on the defects in the taxation of business, rather than investment, income. However the two categories of income are not wholly distinct. The active business income of one corporation can be transformed into "passive" investment income of a related corporation through the use of intercorporate interest or royalty payments. Moreover, there is some fluidity between the bases of the corporate and personal income taxes; as rates of personal income tax go down (whether because of statutory decreases or easier access to avoidance mechanisms), some income tends to shift from corporations to individuals and visa versa.

\section{Avoidance Techniques and Attempted Countermeasures}

Though there may be as many different tax schemes as there are taxpayers, a remarkable number are variations on one, relatively simple pattern: income earned from products or services that are manufactured, produced or sold (and sometimes all three) in high tax jurisdictions is diverted to a foreign corporation, the income of which is taxable neither by the source nor by the residence country. Source country tax is avoided either because such taxation is precluded by treaty or the income is derived in exempt form; residence country taxation is avoided by locating the corporate entity in a "tax haven" jurisdiction. ${ }^{26}$ To take one simple example, a company, $\mathrm{P}$, that makes widgets may create a subsidiary, S1, to perform the actual manufacturing in high tax country A. The

to an income measurement. Part III.C.2.d infra discusses whether a gross receipts tax would be an acceptable source-based income tax.

${ }^{22}$ Taxing authorities have little in the way of extraterritorial power; indeed, as a general rule their agents are not allowed to operate abroad. Further, although foreign governments may provide some assistance with auditing and collection activities under the terms of tax treaties, for the most part, noncooperation is the rule.

${ }^{23}$ See StAFF OF THE JoInT Comm. On TAXATION, supra note 5, at 391 ("Congress believed that the imposition of a withholding tax on portfolio interest paid on debt obligations issued by U.S. persons might impair the ability of U.S. corporations to raise capital in the Eurobond market.”).

${ }^{24}$ See United States Model Income Tax Convention of November 15, 2006, Art. 11, ๆ 1 (providing that "Interest arising in a Contracting State and beneficially owned by a resident of the other Contracting State may be taxed only in that other State.”); id. at Art. 12, \ 1 (same for royalties “arising in a Contracting State and beneficially owned by a resident of the other Contracting State”); id. at Art. 10 (limiting source country taxation on dividends to 5 or $15 \%$ of gross dividend income depending on degree of ownership by dividend recipient).

${ }^{25}$ For a more complete exposition of this thesis, see Julie Roin, Rethinking Tax Treaties in a Strategic World With Disparate Tax Systems, 81 VA. L. REV. 1753 (1995).

${ }^{26}$ A country may constitute a "tax haven" either because it levies no, or low income taxes generally, or because it operates a "territorial tax system," and excludes foreign sourced income from its tax base. 
widgets cost $\$ 60$ to produce. S1 sells the widgets for $\$ 62$ to a related company, S2, which is resident in a tax haven jurisdiction B. S2 sells the widgets for $\$ 80$ to S3, yet another related company resident in the U.S. S3 distributes the widgets throughout the U.S. market, selling them to unrelated U.S. customers at an average of $\$ 90$, after incurring expenses of about \$5 per widget. S1's profit of \$1 per widget is taxable in $\mathrm{A}$. S3's profit of \$5 per widget is taxable in the U.S. But S2's profit of \$21 per widget is taxable only in $\mathrm{B}$, a country which by definition levies very little tax. It is not taxable in A because none of S2's income is derived from A; all it does in A (if it does anything at all) is purchase goods there. S2's income is not taxable in the U.S. because it is not engaged in a trade or business in the U.S. nor does it have an office or fixed place of business in the U.S.; even if the gains from S2's sale of widgets would be sourced in the U.S. under the U.S. source rules, the gains would be exempt from the withholding tax. These results are particularly galling when, as is often the case, S2 is a mere shell corporation, with few employees or activities to justify its reaping the lion's share of the income generated by the corporate group.

The U.S., like most high tax countries, has tried to attack such schemes, both through administrative actions, legislative enactments and renegotiation of tax treaty terms. However, as described in greater detail below, taxpayers have managed to keep one step ahead of the U.S. and other governments. At best, taxing authorities have found themselves engaged in a never-ending game of "whack-a-mole"; more often they appear to be looking on helplessly as the moles eat the produce in the garden and move inexorably closer to the foundations of the house.

\section{A. Transfer Pricing}

The tax avoidance scheme outlined above works only when the widget prices used by the taxpayer in the transfers between S1, S2 and S3 are accepted as legitimate for purposes of calculating the taxable income of the affected corporations. Under the laws of most countries, the terms of transfers between related parties must approximate "arms length" terms; that is, the prices used must be the same as those that would be charged unrelated purchasers of the goods or services involved. If the transfer prices do not meet this arms length standard, the tax authorities may step in and reprice transactions for purposes of computing the affected taxpayers' tax obligations. Both U.S. statutory law ${ }^{27}$ and treaty provisions ${ }^{28}$ allow tax authorities to "adjust" the income, deductions, credits and other tax attributes to bring the tax results of related party transactions into conformity with the results that would have followed from the use of arms length pricing terms. But conferring this power on tax authorities is easy. Tax authorities have found it remarkably difficult to effectively exercise this power.

One problem is that few intercompany transfers involve fungible items with clearly defined market prices. $^{29}$ As a result, it is very hard to identify comparable transactions taking place between unrelated parties to serve as the third party standard.

\footnotetext{
${ }^{27}$ See I.R.C. § 482 .

${ }^{28}$ See United States Model Income Tax Convention of November 15, 2006, Art. 9 (Associated Enterprises); OECD Model Income Tax Convention, Art. 9.

${ }^{29}$ As early as the 1970's, government reports showed that only about 3 percent of transfer pricing disputes relied on "comparable uncontrolled transactions" as a basis for making transfer price adjustments. See Stanley I. Langbein, The Unitary Method and the Myth of Arm’s Length, 30 TAX NoTES 625, 657 (1986).
} 
Intellectual property that is both unique and difficult to value, ranging from trademarks, to patents, marketing intangibles, or goodwill, infects almost every transaction. At best, taxpayers and tax authorities find themselves relying on loosely similar transactions, and then arguing about the type and extent of corrections necessary to make the price terms reasonably comparable.

Not only is the end of such pricing disputes in much doubt, but the process of reaching that end is burdensome in the extreme for both governments and the affected taxpayers. Transfer pricing disputes often degenerate into very expensive contests of dueling experts, sapping the resources of both taxpayers and tax authorities. ${ }^{30}$ Though one might think that the prospect of being embroiled in such a dispute would lead taxpayers to use conservative pricing assumptions, the corresponding inability of tax authorities to challenge more than an infinitesimal proportion of related party transactions seems to encourage taxpayers to play the audit lottery.

The U.S. also utilizes a tool developed to combat other forms of tax avoidance to try to stem transfer pricing abuses. It now encourages taxpayers to justify their transfer prices or transfer price methodology in advance of entering into related party transactions. $^{31}$ The hope is twofold: first, that the discipline of the justification process will prevent gross overreaching by taxpayers and second, that forcing taxpayers to make pricing choices at least somewhat in ignorance of actual business outcomes will somewhat constrain their ability to pick tax minimizing transfer prices. ${ }^{32}$. Whether this tool will be worth the substantial costs imposed on taxpayers (whether overreaching or not) remains open to debate. Hindsight is not necessary in many cases to determine the tax minimizing transfer price strategy, and the corresponding justification for the desired results often not difficult to construct.

Not only is such intellectual property extraordinarily difficult to value, ${ }^{33}$ but taxpayers have learned to transfer ownership of such property, and thus the associated income, to foreign corporations over which the source county has limited taxing jurisdiction. ${ }^{34}$ Such property, which typically lacks physical existence, is eminently moved through paper transactions. Nor is intellectual property the only intangible whose

\footnotetext{
${ }^{30}$ See Reuven S. Avi-Yonah, supra note 6 , at 151("For the vast majority of taxpayers, the result [of traditional arm's length standard] is years of uncertainty before a case can be settled or litigated.”); Stanley I. Langbein, supra note 29, at 627 ("the rules create considerable uncertainty and administrative burden"); Diane M. Ring, On the Frontier of Procedural Innovation: Advance Pricing Agreements and the Struggle to Allocate Income for Cross Border Taxation, 21 Mich. J. OF INT'L LAW 144, 145 (2000) (“there has developed a national, and even international consensus that traditional mechanisms for administering the law and resolving disputes have virtually collapsed in the area of transfer pricing”).

${ }^{31}$ Taxpayers can avoid risking imposition of the "substantial understatement" penalties contained in I.R.C. § 6662(e), should they be on the losing end of a transfer pricing dispute, by meeting the “contemporaneous transfer pricing documentation” requirements of Treas. Reg. § 1.6662-6(d)(2)(iii). These penalties are substantial, ranging from 20 to 40 percent of the amount of any tax understatement. See Michael J. Graetz, Foundations of InTERnAtional InCOME TAXATION 421-422 (2003).

${ }^{32}$ See T.D. 8519, 1994-1 C.B. 298 , 299 (1994) (Preamble to Temporary Regulations promulgated under authority of I.R.C. § 6662(e)).

${ }^{33}$ See Charles E. McClure, Jr., U.S. Federal Use of Formula Apportionment to Tax Income from Intangibles, 14 TAX NOTES INT'L 859, 859 (1997).

${ }^{34}$ See, e.g., Glenn R. Simpson, Wearing on the Green: Irish Subsidiary Lets Microsoft Slash Taxes in U.S. and Europe; Tech and Drug Firms Move Key Intellectual Property To Low-Levy Island Haven; Center of Windows Licensing, Wall Street Journal, Nov. 7, 2005, at A-1.
} 
ownership can be (and often is) manipulated for tax purposes. It is not clear, as a theoretical matter, which member of a group of related entities is entitled to reap the benefits of more traditional, and possibly less unique, location factors, such as unusual market or supply opportunities: should the resulting gains be allocated to the entity located in the location with the special factor, the entity whose employees identified the existence of the special factor, or should the special gains be distributed among all participating entities? ${ }^{35}$ Given this uncertainty, taxpayers usually take pains to ensure that these "assets" and associated gains are assigned to entities resident in low tax jurisdictions. Finally, it is unclear how to allocate gains generated by vertical integration among vertically integrated entities. ${ }^{36}$

The limited prospects for success of direct attacks on transfer price abuses and intangibles allocation has led governments to adopt other, more indirect methods of controlling tax avoidance activities. One such technique is to reduce the tax effectiveness of foreign corporations, either by redefining those corporations as domestic corporations subject to domestic tax on world wide income or by taxing the domestic shareholder of those corporations on their share of the corporate earnings on a current basis. These techniques, and the ways taxpayers have bypassed them, are discussed in the next section.

\section{B. Domesticating Foreign Corporations}

One of the problems with the current U.S. tax rules is that they make it very easy for taxpayers to form foreign corporations such as S2 to be used in tax minimization schemes. The residence of natural persons, not surprisingly, is generally determined by their physical location - either by their personal abode or by the location of their workplace. ${ }^{37}$ Although some people divide their time among so many jurisdictions that it becomes difficult to discern their primary affiliation, relatively few problems arise in determining the residence of natural persons. The residence of corporations, however, is another matter entirely. The U.S., like most countries, as a general rule determines corporate residence on the basis of where the company is incorporated, ${ }^{38}$ which

\footnotetext{
${ }^{35}$ See Richard Vann, Problems in International Division of the Business Income Tax Base, (linking source allocations to Coase's theory of firm value).

${ }^{36}$ See Reuven S. Avi-Yonah, supra note 6, at 148-149 ("This residual, the result of the interaction among the constituent parts of the organization, cannot be assigned to any component. Any transfer pricing rule which arbitrarily assigns the residual to one part of the organization distorts economic reality.”); Stanley Langbein, supra note 29, at 669 ("[I]n a system in which hierarchy has displaced a market form, the net revenue (return) to the entire system will exceed at least the apparent aggregate of the individual revenues imputable to the components under any kind of marginal costing notions."); Note, Multinational Corporations and Income Allocation Under Section 482 of the Internal Revenue Code, 89 HARV, L. REV. 1202, 1215 (1976) ("In economic theory, affiliates of a MNC would not necessarily be expected to treat other affiliates as wholly separate corporations or to choose arm's length prices for their transfers, since affiliation may give rise to a variety of synergistic effects which alter the costs and benefits of transacting intercompany business....”).

${ }^{37}$ See I.R.C. §§ 7701(a)(30), 7701(b). The U.S. looks at residency rights as well as physical residence, including within its definition of U.S. resident both U.S. citizens, wherever physically resident, and possessors of U.S. "green cards" or permits for "lawful permanent residence."

${ }^{38}$ See I.R.C. § 7701(a)(4). In the late 1990's and early years of the $21^{\text {st }}$ century, some U.S. multinationals entered into "inversion transactions" to turn themselves into foreign multinationals. See Michael S. Kirsch, The Congressional Response to Corporate Expatriations: The Tension Between Symbols and Substance in the Taxation of Multinational Corporations, 24 VA. TAX REV. 475, 477 n.1 (2005) (listing transactions). In a typical inversion transaction, shareholders of the U.S. parent corporation exchange their shares for shares
} 
essentially is a function of where its incorporators choose to file the incorporation papers. Although some serious, non-tax legal consequences, such as the extent of shareholder rights, can be determined by the country of incorporation, ${ }^{39}$ the contours of an acceptable corporate law regime are fairly well known and relatively noncontroversial. ${ }^{40}$ As a result, many countries have adopted legal regimes acceptable both to investors and corporate management. In particular, such regimes can be adopted by low tax countries anxious to serve as tax havens for large multinational companies and investors. ${ }^{41}$ There are, in short, many locales willing and able to serve as S2's country of residence. ${ }^{42}$ The costs of

in a newly formed foreign subsidiary resident in a tax haven jurisdiction. That foreign subsidiary then becomes the new parent corporation. Id. at $478 \mathrm{fn} .2$. Congress responded by enacting IRC $\S 7874$ as part of the American Jobs Creation Act of 2004. See id. at 483. This section of the Code disregards inversion transactions in which shareholders of the old U.S. corporation constitute more than 80 percent of the shareholders of the new foreign parent and continues to treat the foreign parent as a U.S. corporation for tax purposes. See I.R.C. § 7874(b). Where between 60 and 80 percent of the shareholder groups overlap, the foreign parent is respected as a foreign entity, but the gain generated by the inversion transaction cannot be offset by tax attributes of the U.S. corporation, nor are any associated transactions eligible for nonrecognition treatment for 10 years following the inversion transaction. See I.R.C. §§ 7874(a), 7874(d)(2)(A). In addition, some types of intellectual property income earned by the foreign parent remains subject to U.S. taxing jurisdiction. Id. $\$ 7874(\mathrm{~d})(2)(\mathrm{B})$. However, the section has no impact on corporations which start out as foreign corporations, nor on transactions in which the old shareholders own less than 50 percent of the new parent, nor when the new parent carries out substantial business operations in its country of incorporation. In January, 2007, Senators Dorgan, Levin and Feingold introduced a bill that would extend the approach of the anti-inversion rules by treating as domestic corporations all "controlled foreign corporations" incorporated in one of forty identified "tax haven countries." See Alison Bennett, Momentum Increasing for Tax Haven Limits As Budget Writers Eye Dorgan Bill for Offset, 56 DAILY TAX REP'T G-5, G-5 (2007). Like the original anti-inversion rules, the rules contained in the new bill would affect new multinationals originally incorporated outside the U.S., nor foreign corporations otherwise falling outside the definition of a "controlled foreign corporation."

${ }^{39}$ See Michael S. Kirsch, supra note 38, at 552-556 (detailing controversy over changes in shareholder rights resulting from inversion transactions); David Cay Johnston, Bermuda Move May Sound Good, But Investors Could Get Burned, N.Y. TIMES, June 13, 2002, at C-1 (same).

${ }^{40}$ The states of the United States have had no difficulty copying Delaware's statute, for example. See Edmund W. Kitch, The Simplification of the Criteria for Good Corporate Law or Why Corporate Law Is Not As Important Anymore, 2 BERKELEY Bus. L.J. 35, 36 (2005) (consensus has led to "the notable convergence of U.S. corporate laws”). The European tradition is different, but more in its choice of means than of the ends to which their laws are directed. See Sophie Cools, The Real Difference in Corporate Law Between the United States and Continental Europe: Distribution of Powers, 30 DEL. J. CoRP. L. 697, 763 (2005) (investor protection achieved by giving shareholders greater influence over management decisions). ${ }^{41}$ These rights can also be provided by private contract. At least one commentator has suggested that the New York Stock Exchange require foreign corporations seeking to list on that exchange meet the corporate governance standards set for domestic corporations; at present, foreign corporations are subject to lower standards. See John C. Coffee, Jr., Racing Towards the Top?: The Impact of Cross-Listings and Stock Market Competition on International Corporate Governance, 102 ColuM. L. REV. 1757, 1830 (2002). However, others are advocating further lowering the listing standards for foreign companies. See Floyd Norris, High and Low Finance; Should U.S. Markets Be Wide Open?, N.Y. TIMES, Feb. 9, 2007, at C1. ${ }^{42}$ Some have suggested that high tax countries buy off tax haven countries by entering into "tax flight" treaties. See Steven Dean, Philosopher Kings and International Tax, 58 HASTINGs L.J. _ _ (forthcoming 2007). Such proposals run into a number of practical obstacles. One is that it may be impossible to get the high tax countries to agree on how to split the costs of obtaining such treaties. Another is that the list of tax haven countries is not stable- over time, countries can and have added themselves to (and less frequently subtracted themselves from) the list. And as old, established tax haven countries are bought out, the benefits to the remaining tax haven countries will increase, attracting new tax haven entrants. Not all countries can become tax havens of course; enacting the "right" laws is not enough if a country is generally 
setting up an S2 in most of these jurisdictions is quite low, especially relative to the amount of taxes saved.

Some countries have tried to attack the problem of tax haven entities by adopting less formal, and hopefully less manipulable, definitions of corporate residency than the "place of incorporation" rule. Britain, for example, determines corporate residency in part on the basis of its country of "effective management and control." ${ }^{43}$ However, in actual practice, that rule often has come to mean that corporate residency depends on where a company holds its board of directors' meetings, and where it has its primary bank account. ${ }^{44}$ Neither presents much of a barrier to tax avoidance; most directors are happy to spend a weekend or two on a nice beach, and in today's wired environment, bank accounts can be located anywhere.

Some commentators have suggested that corporate residency be determined by the location of the corporate headquarters, where the corporation's high executive officers execute their duties on a day to day basis. ${ }^{45}$ They reason that people, unlike corporate documents, have sincere attachments to physical locations or at least the people who live there. Though executives may be happy to spend a weekend or even a week or two in the Cayman Islands to achieve tax advantages, they and their families will be less enthused about living there full time. Others view such suggestions as impractical. ${ }^{46}$ Certainly changing the residency rules in this way would be a calculated risk, as there is more than minimal chance that some corporations would move their offices to low tax jurisdictions. $^{47}$ Indeed, some taxpayers already seem to be doing this. On March 11, 2007, Halliburton announced that it was relocating its chief executive to Dubai. ${ }^{48}$ Though company officials claimed that the reason for the move was to bring those offices

lawless. See, e.g., Ernest Larkins, Multinationals and Their Quest for the Good Tax Haven: Taxes Are But One, Albeit an Important, Consideration, 25 INT'L LAWYER 471, 472-473 (1991) (listing nontax factors); Dhammika Dharmapala and James R. Hines, Jr., Which Countries Become Tax Havens? (December 2006), http://ssrn.com/abstract=95272..

43 See DAniel SAndler, Tax Treaties And Controlled Foreign Corporation Legislation: Pushing THE BOUNDARIES 3 (1998).

${ }^{44}$ See Hugh J. Ault, Comparative Income TAXAtion: A Structural Analysis 371-373 (1997).

45 The British taxing authorities considered, and rejected, switching to such a rule in 1980. See DANIEL SANDLER, supra note 43, at 3-4. For more recent suggestions, see, e.g., STAFF OF JOINT COMM. ON TAXATION, $109^{\mathrm{TH}}$ CONG., $1^{\mathrm{ST}}$ SESS., OptiOnS TO IMPROVE TAX COMPLIANCE AND REFORM TAX EXPENDITURES 179-80 (Comm. Print 2005); OECD TECHNiCAL AdVISORY Group, PlaCE Of EFFECTIVE

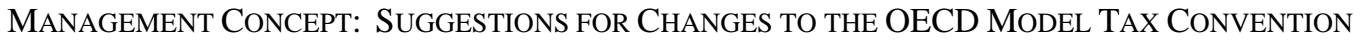
(Discussion Draft 2003); Reuven Avi-Yonah, The Ingenious Kerry Tax Plan, 103 TAx Notes 477, 479 (2004); Arthur J. Cockfield, The Rise of the OECD as "Informal World Tax Organization” Through National Responses to E-Commerce Tax Challenges, 9 YALE J.L. AND TECH. 59, (2006) (discussing OECD recommendations); Michael S. Kirsch, supra note 38, at 583-584; Hale E. Sheppard, Fight or Flight of U.S.-Based Multinational Businesses: Analyzing the Causes for, Effects of, and Solutions to the Corporate Inversion Trend, 23 Nw. J. INT’L L. \& Bus. 551, 578-579 (2003).

${ }^{46}$ See Aldo Forgione, Clicks and Mortar: Taxing Multinational Business Profits in the Digital Age, 26 Seattle U. Law. Rev. 719, 726 (2003); Report of the Task Force on International Tax Reform, 59 TAX LAW. 649, 752-753 (2006); David R. Tillinghast, A Matter of Definition: "Foreign" and "Domestic" Taxpayers, 2 INT’L TAX \& BUS. LAW. 239, 261-262 (1984).

${ }^{47}$ See Richard Vann, supra note 32, p. 28 (detailing movement of key personnel to "regional headquarters" in tax favorable jurisdictions); Martin A. Sullivan, A Challenge to Conventional International Tax Wisdom, TAX Notes 951, 953 (2006) (“[W]e now have the phenomenon of 'runaway headquarters.””).

${ }^{48}$ See Clifford Krauss, Halliburton Moving Its CEO From Houston to Dubai, N.Y. TIMES, March 12, 2007, at A16. 
closer to the company's center of business operations, and that only company offices were being moved and not its country of incorporation, many outside observers speculated that the office move was part of a multiyear, multistep process which will lead to its eventual reconfiguration as a foreign corporation, with significant tax consequences. ${ }^{49}$ And, of course, the more corporations that move their offices to any particular low tax jurisdiction, the more likely it is that other corporations would follow them there. Should multinational corporations move to tax haven countries, high tax countries will be left with neither the tax base they desired nor the jobs those management operations supplied. Short term gains from changing to a less "manipulable" rule, in short, may be more than offset by long term losses.

Further, at an operational level, such proposals for amending the definition of corporate residence will lead to ambiguity. Should one look to the location of the day to day activity of each particular corporate entity-including entities which may not have much day to day activity - to determine the residence of that particular company, or should one determine the residency of all the members of a related group of companies by reference to the residence of the parent company? What if, as an operational matter, the management functions of a vertically integrated group of companies are carried out by a "subsidiary" in the corporate structure, which enters into a "management contract" with the ostensible parent company? What seems like a sensible rule in the abstract may fall apart quite quickly in the real world where taxpayers have financial incentives to create difficult situations.

Others have suggested that it may make more sense to have tax consequences depend on the residence of a corporation's shareholders rather than the residence of the corporation itself. ${ }^{50}$ To some extent, this is what the various base company tax regimes, including the subpart F regime found in the U.S., do. More recent shareholder based proposals suggest integrating the corporate and individual income tax and marking to market all investments on publicly traded stock. Each of these approaches has problems, along with possibilities.

\section{Domesticating Foreign Corporation Income}

It is not necessary to turn S2 into a domestic corporation (or a corporation domestic to another high tax jurisdiction) to subject its income to tax in a high tax country. One can achieve a comparable tax effect by subjecting the domestic owners of S2 to tax on their share of S2's income as S2 earns it. Although in general, shareholders of corporations do not pay tax on their share of the corporation's income unless and until

\footnotetext{
49 See Clifford Krauss, Halliburton Office Move Is Criticized, N.Y. TIMES, March 13, 2007, at C1. Most likely, this inversion transaction will occur following the 2009 expiration of the temporary I.R.C. § 954(c)(6) exemption of certain related party payments from subpart F income. Prior to 2009, this exemption is probably sufficient to allow other foreign Halliburton subsidiaries operating in high tax jurisdictions to move income out of potentially high taxed foreign entities and into Halliburton's low taxed Bermudan subsidiary without running afoul of the U.S. subpart F regime. By 2009, Halliburton's office move will be "old and cold"; it can then be used as evidence of the history of foreign business and management necessary to exempt Halliburton from the strictures of the I.R.C. $§ 7874$ antiinversion rules. See I.R.C. § 7874(a)(2)(B)(iii). As explained infra TAN 58-59, Halliburton will not have to worry about the subpart $\mathrm{F}$ regime once its parent corporation is a foreign corporation.

${ }^{50}$ But see Richard Vann, supra note 32, at 11 (outlining “practical considerations” militating against a shareholder based rule of corporate residence).
} 
the corporation distributes a dividend to them or they sell their shares of corporate stock, exceptions have always been made to that general rule. And, of course, if P or P's shareholders pay a contemporaneous tax on S2's earnings, they gain nothing from the interposition of S2 in the corporate structure; the taxes paid will be the same as would have resulted from S1 contracting directly with S2. There are two ways in which such contemporaneous taxation could be effected. One has been tried, the other merely suggested.

\section{Base Company Regimes}

The U.S. was one of the first, if not the first, nation to enact a statutory regime that imputes the income of foreign subsidiaries to their domestic shareholders on a current basis. Under the subpart F regime, enacted in 1962, the U.S. shareholders of controlled foreign corporations are forced to include in their income "constructive dividends" equal to their pro rata shares of those corporations' subpart F income. ${ }^{51}$ These constructive dividends are included in the income of the U.S. shareholders of the foreign subsidiary corporations in the year the underlying income is earned by the foreign entity; this "deeming" thus eliminates the advantage of using a tax haven entity because the shareholder has to pay the U.S. Treasury the difference between the amount of foreign taxes paid by the foreign subsidiary and the amount of tax that would have been payable with respect to that income had it been earned directly by the U.S. shareholder. Although some of the taxes paid with respect to such an entity's income may go to that entity's country of nominal residence, because of the immediate constructive dividend, the total foreign and U.S. tax paid with respect to income affected by the regime is the same in both nominal dollars and time value of money terms as if that income had been earned directly by the U.S. shareholder(s).

This statutory regime is extremely complex in part (but only in part) because its reach is fairly narrow. Only U.S. persons holding fairly significant ownership interests in the foreign entity are considered "U.S. shareholders" for purposes of deemed dividend distributions. ${ }^{52}$ Further, foreign subsidiaries are deemed to distribute as current dividends only specific, disfavored types of income. ${ }^{53}$ The precise contours of this disfavored income, or "subpart F income", have changed over time, but the definition has always included a combination of passive income, other mobile income, and income generated in the context of certain related party transactions. Subpart F income does not include income generated by active business operations such as manufacturing.

There are a number of ways to escape the application of the subpart $\mathrm{F}$ tax regime. One option, of course, is for the subsidiary to conduct active, income generating activities in its country of residence. But taxpayers do not have to go to that trouble, particularly now that much of the value of an enterprise stems from ownership of intellectual property

\footnotetext{
${ }^{51}$ I.R.C. § 951(a)(1).

${ }^{52}$ See I.R.C. § 951(b) (a U.S. person must directly or indirectly own at least 10 percent of the shares of the controlled foreign corporation to be deemed a "United States shareholder").

53 See I.R.C. § 952 (defining “subpart F income”). The scope of this definition seems to shrink with every tax act. See Tax Relief and Health Care Act of 2006, P.L. 109-432, § 426(a)(1)(A), 120 Stat. 345 (2006), amending Tax Increase Prevention and Reconciliation Act of 2005, P.L. 109-222, § 103(b), 120 Stat. 345 (2006) (codified, as amended, at I.R.C. § 954(c)(6)) (narrowing the definition of "foreign personal holding company income” to allow "redeploy[ment of] active foreign earnings with no additional tax burden”). H.R. REP. No. 109-304, at 45 (2005).
} 
or marketing intangibles. Many taxpayers contract with companies, often but not always located in high tax countries, to carry out manufacturing or distribution functions. These contractual parties earn relatively meager returns (thereby engendering relatively meager tax liabilities even if operating in high tax jurisdictions); most income accrues instead to the tax haven corporation which retains ownership of both the high value manufacturing and marketing intangibles and bears most of the enterprise's business risk. Because, as a technical matter, the income generated by these tax haven corporations comes from manufacturing, ${ }^{54}$ their income falls outside the definition of subpart F income, and hence, their shareholders escape the subpart F regime. ${ }^{55}$ These contractual arrangements may involve related or unrelated manufacturers or distributors. One of the Tax Court cases in which the taxpayer prevailed involved a related contract manufacturer, ${ }^{56}$ while another involved an unrelated manufacturer. ${ }^{57}$

Alternatively, the multinational entity may be structured to avoid creation of a U.S. shareholder to whom subpart F income could be attributed. This is accomplished by placing any U.S. corporations at the bottom of the corporate chain and making the upper level corporations residents of low tax jurisdictions, essentially "inverting” pre-existing corporate structures. Dividends, after all, stream upwards in an ownership chain; if the upper levels of the chain are all foreign, the U.S. has no jurisdiction to tax dividends, imputed or otherwise. And the shareholders of a publicly held foreign parent company generally have too small a stake in the enterprise to constitute "U.S. shareholders" under the applicable statutory rules, ${ }^{58}$ even if all are U.S. citizens. Although the U.S. has enacted legislation which make it more expensive and sometimes impossible to invert existing corporate structures with U.S. parent companies, ${ }^{59}$ the legislation has no impact on corporate structures initially constructed with a foreign parent or which are taken over by substantial, preexisting foreign corporations. At best then, the new anti-inversion statute slows the transition away from U.S. based multinationals to foreign based ones that lie outside the range of subpart F.

\footnotetext{
54 The IRS allowed the imputation of the manufacturing activities to the tax haven corporation in Rev. Rul 75-7, 1975-1 C.B. 244, although it undercut the favorable tax implications of this imputation by treating the manufacturing company as a "branch" of the tax haven entity. When taxpayers prevailed against IRS attempts to apply the "branch rule" in two Tax Court cases, the IRS revoked Rev. Rul. 75-7 in Rev. Rul. 97-48, 1997-2 C.B. 89. See Barbara M. Angus and Thomas M. Zollo, Revisiting the U.S. Taxation of Intangible Property Income of Controlled Foreign Corporations, 84 TAXES 75, 78-79 (2006). Although Treasury officials are far from sanguine about the extent of taxpayers' claims to manufacturing imputation, and hence their exemption from subpart F strictures in these contract manufacturing situations, see Alison Bennett, Guidance on Contract Manufacturing in CFC Context Under Way, Hicks Says, 16 DAILY TAX REP'T I-2, I-2-I-3 (January 25, 2007), even they agree that "real CFC principals providing real value-driven functions” should be treated as manufacturers, an opinion shared by practitioners. See Barbara M. Angus and Thomas M. Zollo, supra, at 81-82.

${ }^{55}$ Pure sales income can be treated as subpart $\mathrm{F}$ income, but income derived from the manufacture and sales of goods is not. See Treas. Reg. $§ 1.954-3(a)(4)(i)$.

${ }^{56}$ See Vetco, Inc. v. Cmm'r., 95 TC 348 (1990).

${ }^{57}$ See Ashland Oil, Inc. v. Comm’r, 95 T.C. 348 (1990).

${ }^{58}$ See I.R.C. § 951(b) (“the term 'United States shareholder’ means...a United States person...who owns...or is considered as owning...10 percent or more of the total combined voting power of all classes of stock entitled to vote of such foreign corporation.”).

${ }^{59}$ See I.R.C. § 7874 and note 38 supra.
} 
Other countries have enacted variants of the subpart F regime. ${ }^{60}$ Some, such as Germany and Canada, deem dividends paid to a broader slice of domestic shareholders or apply to foreign corporations in which domestic investors have substantial but not controlling interests. ${ }^{61}$ Some limit the application of the regime to domestic taxpayers having an intent to avoid taxes. ${ }^{62}$ Some deem dividends only of passive income earned by the foreign corporation; ${ }^{63}$ others apply to all the income earned by related entities in "black listed" jurisdictions, or by companies that are not resident in a "white listed" jurisdiction. ${ }^{64}$ Most of the avoidance possibilities depend on the precise configuration of the underlying statutory regimes, but careful structuring of the overall entity to include a foreign parent always works to escape the strictures of these regimes. ${ }^{65}$ Now that it is relatively easy for the shares of companies based in tax haven countries to be sold in established securities markets, ${ }^{66}$ there is little reason for corporations to be residents of high tax countries.

\section{Integration-based proposals}

The mutability of corporate residence and structure has led some to suggest that it would make sense to focus taxation on individual shareholders who are far less mobile than artificial entities like corporations. Such proposals inevitably involve reducing the current two-level corporate tax to one, since it seems impolitic to attempt to collect two levels of tax directly from individual taxpayers. The suggestion that has been proposed most often is simply to move to mark to market taxation of publicly traded stock. ${ }^{67}$ The

\footnotetext{
${ }^{60}$ See OECD, ConTROLled Foreign Company LEgisLation 21 (1996) (14 OECD countries and one nonOECD country have CFC legislation).

${ }^{61}$ See DANIEL SANDLER, supra note 43, at 25 (Germany); id. at 26.

${ }^{62}$ See OECD, supra note 60, at 28 (Italy).

${ }^{63}$ See id. at 46 (Denmark and Norway).

${ }^{64} \mathrm{See} i d$. at 23 (Japan, with disfavored jurisdictions determined by statutory tax rate); id. at 24 (United Kingdom); id. at 25 (New Zealand); id. at 26 (Sweden)

${ }^{65}$ See id. at 32-33 ("A key feature of all CFC regimes is that the legislation only applies to foreign entities over which domestic taxpayers have substantial influence.....generally of a majority of the shares of the corporation.”). The United States' Passive Foreign Investment Company (PFIC) regime, contained in I.R.C. $\S \S 1291$ through 1298 , is an exception to this rule but it applies only to passive investment income earned by U.S. shareholders of foreign investment companies. Though the PFIC rules place no floor on either the individual or aggregate U.S. ownership, removing the economic benefits of deferral from minor U.S. shareholders of largely foreign owned corporations, the regime only comes into play when 75 percent or more of the foreign corporation's gross income consists of "passive income" or at least 50 percent of its assets generate such passive income. See I.R.C. § 1297(a).

${ }^{66}$ One can argue that the worst things to happen to corporate income taxation was the opening of the developed countries' securities markets to foreign issuers. It certainly gave tax haven based companies easier and cheaper access to developed country capital. But foreign companies had long come up with mechanisms to access those markets; moreover, it is possible that failing to open those markets to foreign issuers would simply have led over time to the transfer of those markets (and the associated jobs) to more hospitable jurisdictions. Indeed, some have already begun sounding the alarm over the decline of the primacy of U.S. securities markets. See Keith Bradsher, Hong Kong Set to Be No. 1 in 2006 Offerings, Surpassing London and New York, N.Y. TimeS, Oct. 20, 2006, at C-4; Sewell Chan, Mayor Takes His Message to London, N.Y. Times, Feb. 5, 2007, at C-2; Heather Timmons, New York Isn't the World's Undisputed Financial Capital, N.Y. TIMES, Oct. 27, 2006, at C-1.

${ }^{67}$ See, e.g., Joseph Bankman, A Market Value Based Corporate Income Tax, 68 TAX NoTEs 1347, 1348 (1995); David Slawson, Taxing as Ordinary Income the Appreciation of Publicly Held Stock, 76 YALE L. J. 623 (1967). These pieces are part of a larger discussion on the merits of moving from a realization based
} 
value of stock should, after all, reflect the corporation's total income, including the income of any tax haven subsidiaries. Like all integration proposals, this one raises the issue of what to do about shareholdings of tax exempt entities and, more importantly for purposes of this paper, foreign taxpayers.

Tax exempt entities are a problem because present law's double tax system allows for the collection of a single level of tax on corporate income attributable to shares owned by exempt entities; such entities thus avoid only the second layer of tax on their share of corporate earnings. Elimination of the corporate level tax, in favor of mark to market taxation of increases in share value, would force the U.S. to choose between an all or nothing taxation regime. The first alternative would raise taxes on tax exempt entities, while the second would decrease their tax burden and, accordingly, government revenues.

Of course, even now the portfolio effect minimizes the burden of taxes falling on exempt entities. That is, such tax exempt corporations often invest in bonds rather than corporate stock to maximize their tax advantage. Elimination of the tax on corporate income may change little more than their investment strategies, which is at least arguably a good thing.

The conundrum posed by foreign taxpayers is more difficult. In theory, foreign owners of publicly traded stock should not be taxable on their gains. The tax, after all, is a residence based one; passive foreign investors do not become residents or a nation simply by investing in the shares of corporations resident there or trading on its stock exchanges. From a distributional standpoint, however, that means that substantial amounts of income derived from source country business operations would never be taxed by the source country. The cost of providing the services utilized by those businesses would thus have to be borne entirely by source country residents. In a Coasian world, perhaps that does not matter; the additional taxes should be recompensed by higher salaries and source-country employment-which the source country can tax. The appearance may be worse than the economic reality. Or perhaps not; it depends on how well Coasian bargaining works in the real world. Such a result will certainly be politically unpopular.

Perhaps some of that unpopularity could be diffused by recognition that at least some of the taxes that the source country loses in its status as a source country would be offset by the additional taxes gained by taxing its residents on their foreign source gains, including gains attributable to increases in the value of shares of foreign companies. But the existence (and amount) of such offsets depends on two assumptions. One is that the country's residents earn approximately as much from foreign sources as foreign owners derive domestically. ${ }^{68}$ The other is that the country's residents will honestly report those foreign share earnings to home country tax authorities. Both of these assumptions are questionable. The removal of the withholding tax on portfolio interest

regime to an accrual or mark to market regime. For examples of the larger context, see, e.g., David J. Shakow, Taxation Without Realization: A Proposal for Accrual Taxation, 34 U. PENN. L. REV. 1111 (1986); Victor Thuronyi, The Taxation of Corporate Income-A Proposal for Reform, 2 AM. J. OF TAX POL'Y 109 (1983).

${ }^{68}$ The implicit revenue exchanges would resemble those effectuated by many bilateral tax treaties, whereby countries agree to give up the right to impose source taxes on residents of their treaty partner. In theory, the absence of source taxation leads to higher residence tax collection. The actuality, however, in treaty situations is quite different, see Julie Roin, Rethinking Tax Treaties in a Strategic World with Disparate Tax Systems, 81 VA. L. REV. 1753, 1766-1767 (1995). 
income provided a window into the sorts of compliance problems that are likely to arise. That experience shows that many investors would evade their residence tax obligations by investing in shares of foreign companies and simply failing to report those holdings to the tax authorities of their residence countries. ${ }^{69}$ Absent much more elaborate exchange of information arrangements than currently exist, ${ }^{70}$ the chances of any individual taxpayer being caught are slim. Nor do investors with strong home country biases have to be left behind (though taxpayers with strong ethics would be). They may continue to invest in domestic stocks through a foreign intermediary which, particularly if not publicly traded, would escape notice. The globalization of capital markets continues to make crossborder investing ever easier and cheaper.

Of course, the availability of abnormally high after tax returns made possible by the absence of source or residence taxation may attract more foreign investors in domestic stock. But this may be a mixed blessing, if blessing at all. The additional investment by foreigners may simply substitute for those domestic investors who decide to seek their own tax favored return by investing in (similarly tax favored) foreign stock. The overall amount of investment may change little if at all. Though such avoidance techniques may not be legal (at least under the tax rules of the taxpayer's country of residence), again, the odds of any taxpayer being caught are not high.

Yet, taxing foreigners on their stock market gains has always been problematic because of the limited connection between such shareholders and the country seeking to do the taxing. There is relatively little that source countries can do to enforce such taxes. Often, foreigners do not have cash or assets other than the affected stock located in the tax seeking country. Unlike dividends, there is no cash payment to shareholders out of which the issuing corporation can be forced to withhold and pay the appropriate tax to governmental authorities; this is even more of a problem when dealing with mark to market gains than with actual stock sales. Conceivably, the tax could be enforced as a lien against the affected stock, which then could not be transferred absent payment to the government. $^{71}$ This would place a substantial, and perhaps impossible, burden on financial intermediaries such as brokers. Indeed, at least partly as a result of these administrative problems, current U.S. tax law does not impose a tax on most foreigners' stock market gains, ${ }^{72}$ and tax treaties generally provide equivalent or better protection against source country taxation for stock market gains. ${ }^{73}$

These enforcement problems are hardly unique to a mark to market tax system; indeed, most believe that underreporting of capital gains income under current tax regimes is quite extensive. However, currently the tax being avoided (or evaded) is just

\footnotetext{
${ }^{69}$ See Joe Kirwin, EU Hopes to Extend Savings Tax Agreement To Accounts in Hong Kong, Singapore, Macao, 199 DAILY TAX REP'T G-4 (Oct. 16, 2006) (EU member states unhappy “because they have not recovered the tax revenue they expected with the approval of the EU savings tax directive...[because] millions of its citizens have money hidden in Luxembourg").

${ }^{70}$ As the U.S. has learned, information returns are virtually useless unless they can be machine read and include the taxpayer's home country TIN.

${ }^{71}$ Taxpayers might then try to avoid such rules by holding their shares in entities incorporated in tax haven jurisdictions, and then trading the shares of the intermediating entities.

${ }^{72}$ See I.R.C. §§ 871(a)(2) (nontaxation of capital gains generated by nonresident aliens present in the US for less than 183 days of the current tax year); 881(a) (imposing withholding tax on limited categories of US capital gains).

${ }^{73}$ See United States Model Income Tax Convention of November 15, 2006, Art. 13 (limiting source country taxation of gains).
} 
one of two levels of tax. Realized corporate profits are supposedly being taxed at the corporate level. No such corporate tax would be payable under an integrated mark to market regime.

The limited success of traditional methods of protecting the corporate tax base in a globally integrated economy has led to the recent interest in essentially scrapping the current system for taxing international income, based as it is on arm's length methodology and respect for the individuality of separate legal entities, and replacing it with a method which forces the combination of related entities for tax computation purposes and then allocates the combined income between countries according to a formula based on "real economic factors." It is hoped that such a taxing regime will prevent multinational corporations from being able to isolate their earnings in tax haven entities, and force them to pay taxes commensurate to on the services and other benefits that they enjoy in high tax countries. Those hopes may well be dashed, however, as many of the avoidance techniques honed under current law will prove to be equally effective at undermining the effectiveness of such a formulary taxation.

\section{Formulary Taxation}

Proponents of formulary taxation have a model from which to work: the states of the United States use a formulary method to tax the income derived by multistate businesses. Or, more accurately, the states of the United States use a variety of formulary methods to tax the income derived by multistate businesses, some of which incorporate unitary aspects. Though the variation in methods is far from ideal when it comes to fairly and fully taxing the income of multistate enterprises, the contrast in the relative success of various approaches sheds light on the importance of some design issues and the intractability of others.

A. History of the Formulary Method in the U.S.

The states first used formulary apportionment methods in the late1800s to determine the property tax obligations of transcontinental railroad companies. ${ }^{74}$ The first state to adopt a corporate income tax, Wisconsin, decided to use a similar method when determining its share of the base for its new tax. It explicitly rejected the separate accounting approach as too impractical given the fact that few corporations kept state-bystate calculations of income. ${ }^{75}$ It determined its share of corporate income by relying on a formula based on "business transacted" and "property located" within and without the state. $^{76}$ Other states began enacting their own corporate income taxes following the introduction of the federal corporate income tax in $1913 .{ }^{77}$ Although the "usual practice" under "early state income taxes" was to allow taxpayers to use separate accounting if their accounting records made possible "reasonably accurate" state income

\footnotetext{
${ }^{74}$ Joann M. Weiner, Using the Experience in the U.S. States to Evaluate Issues in Implementing Formula Apportionment at the International Level, OTA Paper 83 (1999), at 6.

${ }^{75}$ Id.

${ }^{76}$ Law of July 13, 1911, ch. 658, 1911 Wis. Laws 984 (cited in 1 JEROME R. HELLERSTEIN AND WALTER Hellerstein, State TAXATiOn $\uparrow 8.02[3]$, at 8-16 fn.43 ( $3^{\text {rd }}$ ed. 2002)).

${ }^{77}$ See Joanne Martens Weiner, Formulary Apportionment and Group Taxation in the European Union: Insights From the United States and Canada, Working Paper No. 8, at 11 (March 2005), http://europa.eu.int/comm/taxation_customs/taxtion/taxation.htm..
} 
determinations, $^{78}$ this practice was beginning to disappear by the late 1930 s. Most state statutes now require formulary apportionment. ${ }^{79}$ The switch to the formulary approach was supported by taxpayers as well as state legislators because it minimized taxpayers' compliance costs. ${ }^{80}$

However, concerns about lack of uniformity surfaced immediately because these tax systems were creatures of state rather than federal law. Taxpayers worried at least as much about the costs of reconfiguring their income statements and defining and measuring the apportionment factors to meet different state standards as they did about the possibility of overtaxation. In response to these concerns, a committee of the National Tax Association ${ }^{81}$ designed a model multistate business income tax in 1922, ${ }^{82}$ and in 1933 the organization recommended that the states adopt the Massachusetts apportionment formula. ${ }^{83}$ This formula equally weighted property, payroll and sales factors. $^{84}$ In 1957, the National Conference of Commissioners on Uniform State Laws ${ }^{85}$ drafted the Uniform Division of Income for Tax Purposes Act (UDIPTA), which was intended to serve as the model for state corporate income tax laws. ${ }^{86}$ Unlike previous uniformity efforts, UDIPTA provided rules for measuring the factors used in the recommended formula and special rules for particularly problematic categories of income. Of the 44 states with broad based corporate income taxes, 21 have adopted UDIPTA and most of the others have similar statutory schemes. ${ }^{87}$ In 1967 , the states created the Multistate Tax Compact and the Multistate Tax Commission to encourage states to adopt uniform state tax laws and regulations, as well as to provide a vehicle for suggesting legislative and regulatory changes. ${ }^{88}$ The Commission also provides a forum for conducting joint audits and resolving disputes. Forty-four of the fifty states participate in the Multistate Tax Commission although only 20 are members of the Multistate Tax Compact. ${ }^{89}$

\footnotetext{
${ }^{78} 1$ JEROME R. HELLERSTEIN AND WALTER HELLERSTEIN, supra note 76, ๆ 8.03, at 8-39.

${ }^{79}$ See 1 JerOME R. Hellerstein AND WALTER Hellerstein, supra, ๆ 8.03, at 8- 40.; Joann M. Weiner, supra note 74 , at 7.

${ }^{80}$ Joann M. Weiner, supra note 74 , at 7 (“A survey taken by the National Tax Association in 1938 revealed that most states and businesses preferred formula apportionment to separate accounting.").

${ }^{81}$ The National Tax Association was comprised of state tax officials. It merged with the Tax Institute of America in 1973 and the combined organization is known as the NTA-TIA. See David M. Hudson \& Daniel C. Turner, International and Interstate Approaches to Taxing Business Income, 6 NW. J. INT’L L. \& Bus. 562, 594 n.195 (1984).

${ }^{82}$ See Joann M. Weiner, supra note 74, at 9.

${ }^{83}$ See id. at 10.

${ }^{84}$ See id.

${ }^{85}$ The National Conference of Commissioners on Uniform State Laws is a non-profit, unincorporated association which has been drafting uniform laws for adoption by state legislatures since 1882 . The commissioners are lawyers - sometimes state legislators, sometimes judges, academics or private practitioners-who have been appointed to serve as state representatives to the Conference. It is supported by appropriations from the participating state governments. See http://www.nccusl.org/Update/DesktopDefault.aspx?tabindex=0\&tabid=11 (as of Feb. 8, 2007).

${ }^{86}$ See Joann M. Weiner, supra note 74, at 10.

${ }^{87}$ Jerome R. HELlerstein AND WALter HeLlerstein, State ANd Local TAXation CASES AND MATERIALs 596 ( $8^{\text {th }}$ ed. 2005).

${ }^{88}$ Joann $\mathrm{M}$. Weiner, supra note 74 , at 11.

${ }^{89}$ See JEROMe R. HELLERSTEIN AND WALTER HELLERSTEIn, supra note 87, at 605 (describing Multistate Tax Compact and Multistate Tax Commission).
} 


\section{B. Description of Formulary Taxation Methods}

The construction of a tax system always involves making choices among plausible alternative rules. This is no less true in the design of formulary tax systems than any other tax system. The prevalence of such choices means that there are almost as many versions of formulary taxation systems as there are jurisdictions that have adopted such methods; it is impossible to describe all of them. Yet all the systems have some common features. In particular, each starts from three building blocks: apportionable income, the apportionment formula, and the definitions of the factors utilized in the apportionment formula. Each of these building blocks, and their available variations, is explored in greater detail below.

1. Apportionable Income, or the Tax Base

The first building block of any formulary tax system is the choice of the tax base. This choice really entails three sub-choices. The first sub-choice is how broadly to cast the income net at an entity level, that is, the extent to which the income of related corporations should be considered when divining the income of a particular corporate taxpayer. The second sub-choice is whether all the income of the taxpayer (however defined) ought to be apportioned by formula, or whether parts of it ought to be specifically allocated on some other basis. The third sub-choice goes to the substance of the rules used to define taxable income, that is, the rules used to determining the amount and items of income included in any given year and the identity and amount of deductions allowed against that income. .

The first question is whether the apportionment formula should be applied solely against the income reported as accruing to the legal entity over which jurisdiction can be claimed, or if the income of that entity should be more broadly defined. As the example in the first part of the article shows, if related entities are engaged in a single, vertically integrated business enterprise, taxpayers may attempt to minimize taxes by strategically setting intercorporate transfer prices, limiting the income deemed earned by an entity resident in or taxable by a high tax jurisdiction. This strategy can be upset by tax authorities' policing of the economic bona fides of the prices used in particular transactions. However, these attacks are always piecemeal in nature. Another, much more categorical approach is to force consolidation of the related companies for tax purposes, either in whole or in part. Essentially, the question is whether the boundaries of legal entities should be respected for tax purposes, or whether "a multiple-entity affiliated corporate group that operate[s] as a single economic enterprise" should be combined into a single unit for tax purposes. ${ }^{90}$ Conceptually, the point of such forced combinations or "unitary taxation" need not be to tax the income of related corporations over which the state would ordinarily have no jurisdiction; it can be instead simply to accurately calculate and tax the income generated by the company over which the state does have jurisdiction. However, some blurring of jurisdictional lines becomes inevitable when an entity's whose income ordinarily would not be taxable in a jurisdiction finds some of its factors attributed to that jurisdiction under the unitary calculation. For example, suppose Corporation A has no office or trade or business in Jurisdiction Y, but $\$ 60$ of its \$100 in total widget sales come from Y. A’s sister corporation, Corporation B,

${ }^{90}$ Joann M. Weiner, supra note 74, at 8. 
sells \$100 in widgets to Y consumers through its sales office located in Y. Under separate entity accounting, Y would not tax A's Y-sourced sales income. But under a formulary unitary method, not only would the income of A and B be pooled for tax purposes, so too would be their factors - and $\$ 160$ of out of the $\$ 200$ total sales factor would be allocable to Y. Whether this leaves the taxpayer better or worse off (in terms of Y tax liablity) depends of course on whether 160/200ths of the combined income of A and B is more or less than 100 percent of B's income.

Although all states that tax corporate income use formula apportionment, only about one third use some version of "unitary" taxation to draw in the income of related out of state corporations; the remainder look solely to the income and factors generated by the individual corporations over which they have jurisdiction. ${ }^{91}$ The problem with conjoining separate entity accounting and formulary taxation is obvious. Taxpayers learn to stuff income (and sometimes factors) into entities lacking jurisdictional ties to high tax states. States' failure to adopt unitary accounting is one reason that the effective state corporate income tax rate "was only a third of the 6.8 percent average statutory state corporate income tax rate."92

For constitutional reasons, the states of the United States can only consider the income and factors of related corporations that are engaged in a "unitary business" with the taxpayer. ${ }^{93}$ There is no easily applied definition of a unitary business; whether one exists or not is determined by all the facts and circumstances of a particular case.

Common control is a necessary but not sufficient criteria for businesses to be considered "unitary." Courts generally look for similarities in business operations or evidence of vertical integration or functional integration which could give rise to economies of scale. Moreover, states' ending point for application of the unitary method is federal consolidated income; they do not extend the unitary concept to foreign corporations lacking significant business presence in the U.S., even if those corporations are functionally integrated with a related corporation's U.S. business operations. The "water's edge" restriction on the reach of unitary taxation is a result of a combination of economic and political pressures placed on those states which flirted with worldwide combination measures. $^{94}$

Further, again for constitutional reasons, the states use their formulas to apportion only the income derived from multistate business activities. Certain types of business income, such as rent received with respect to real property, may be directly allocated to the state in which such property is located. ${ }^{95}$ Other types of income, particularly that determined to be "nonbusiness income," 96 may be allocated to the taxpayers' state of

\footnotetext{
${ }^{91}$ See Martin A. Sullivan, Economic Analysis: Lessons for Congress on Closing Loopholes, 110 TAX NoTES 1024, 1025 (2006).

92 Robert S. McIntrye and T.D. Coo Nguyen, State Corporate Income Taxes 2001-2003 (2005), at 3, http://www.ctj.org/pdf/corp0205an.pdf..

${ }^{93}$ Indeed, they can only take into consideration out-of-state income of the same corporation that is part of the business carried out within the taxing state. See 1 JEROME R. HELLERSTEIN AND WALTER

HELLERSTEIN, supra note 75, 9 8.07[1], at 8-58.

${ }^{94}$ For a trenchant critique of those pressures, see Stanley I. Langbein, supra note 29, at 671-672.

95 JEROME R. HELLERSTEIN AND WALTER HELLERSTEIN, supra note 87, at 617.

96 "Nonbusiness income" is income which does not arise from transactions or activity undertaken in the regular course of the taxpayer's trade or business or which is incidental to that business. See id. at 617-618.
} 
residence or commercial domicile. ${ }^{97}$ When the characterization of a particular income item is questionable, the MTC's regulations mandate its treatment as "business income." "98 The difficulty of distinguishing between business and nonbusiness income has led some states to eliminate the distinction between business and nonbusiness income, but it remains questionable whether states have the constitutional authority to apportion all income. ${ }^{99}$

The broader the income net, however, the more significant the third issue, the issue of how to define the tax base, becomes. As anyone who has taken a tax course knows, the design of any tax system involves numerous choices; it is hardly surprising that different designers have not made the same choices in all or even many cases. Taxing authorities require taxpayers to keep at least one set of books and records detailing their income calculated in accordance with their particular rules. It can be quite difficult for a taxpayer to translate books and records constructed with the demands of one tax authority in mind into the form required by another tax authority with a different set of computational rules. Nor is it easy or costless for taxpayers to construct a separate set of books and records for each taxing authority. But, of course, the broader the reach of unitary systems, the more such translations or sets of books must be maintained by affected taxpayers and their affiliates, since all their income, and all their factors, may have to be reported to each of the jurisdictions involved in the unitary business enterprise in accordance with that jurisdiction's particularized rules. Alternatively, a jurisdiction might allow taxpayers to blend income computed under different statutory standards but this would have its own problems.

One reason that unitary systems have been a viable option for states of the United States is that virtually all the states piggyback to a considerable extent on the federal government's definition of corporate taxable income. ${ }^{100}$ Thus, a minimum of translation or adjustment is required to conform the income statements of a Delaware company to the requirements of, say, Massachusetts. This is not to say that some adjustments, and sometimes considerable adjustments, have to be made to conform the tax bases, but they are relatively minor compared to the differences one finds between the tax codes of various nations.

\section{The Apportionment Formula}

Once the tax base has been determined, that base must be apportioned among the various jurisdictions from which the taxpayer has derived income. This apportionment is accomplished by application of a formula against the tax base. The formula determines the percentage of a taxpayer's tax factors located within in each such jurisdiction; each jurisdiction is then apportioned that percentage of the taxpayer's net income as its tax base. Choosing the appropriate economic factors and deciding how much weight to accord the chosen factors in the formula are thus the critical design issues. The

\footnotetext{
${ }^{97}$ See id.

${ }^{98}$ See id. at 618.

${ }^{99}$ See id. at 627; Michael J. McIntyre, Paull Mines and Richard D. Pomp, Designing a Combined Reporting Regime for a State Corporate Income Tax: A Case Study of Louisiana, 61 LA. L. REV. 699, 722 (2001) (contending elimination of distinction unconstitutional).

${ }^{100}$ The Canadian system of provincial taxes carries this uniformity to the extreme. The provinces follow the federal government's rules completely, in return for the federal government's carrying out of the collection and auditing function. See Joann Martens-Weiner, supra note 6, at 68.
} 
Massachusetts formula originally recommended by the National Tax Association called for equal weighting of three factors: payroll, sales and business property. Even before the economic literature began suggesting that "to the extent tax rates vary across

jurisdictions, formula-apportioned corporate income taxes are similar in their incidence to a set of implicit excise taxes on the apportionment factors," ${ }^{\prime 101}$ though, some U.S. states had begun moving towards formulas placing more weight on the sales factor. ${ }^{102}$ This trend has accelerated as state legislatures have become convinced that sales are the least manipulable of the factors. Currently, "almost three-fourth of the states that have corporate income taxes place at least half the weight on sales, and eight base apportionment solely on sales." "103 Most of the remainder are natural resource rich states which do not have to worry about business relocations. ${ }^{104}$

This description illustrates one salient fact about formulary apportionment that is often overlooked: it does not eliminate tax competition. Taxpayers operating under formulary apportionment regimes can reduce their tax liability by relocating tax factors from high tax to low tax jurisdictions. The question then becomes whether such relocation is possible. One consideration in choosing factors must be the ease (or not) of such relocations, both real and virtual.

\section{The Apportionment Factors}

A variety of factors have been utilized over the years. An initial criteria, of course, is that the factor be seen as causally related to the production of income; only that relationship makes its use politically, constitutionally (in the U.S.), and economically acceptable. In the early days of formulary apportionment, sixteen states used formulas taking multiple factors into account, including property, payroll, sales, manufacturing costs, purchases, expenditures for labor, accounts receivable, net cost of sales, capital assets, and stock of other companies. ${ }^{105}$ Over time the trend has been towards the use of a smaller number of factors, typically some combination of property, payroll, and sales. ${ }^{106}$ This combination formula appears to split income, and thus tax revenue, between the jurisdictions in which the taxpayers engage in their business activities and those from which they derive revenue. Most states rely on UDITPA's definition of these factors.

\section{a. Payroll}

Payroll is defined as the total amount paid for compensation of employees, including wages, salaries, commissions and in-kind payments such as rent and housing.

\footnotetext{
${ }^{101}$ See Charles E. McClure, Jr., The State Corporate Income Tax: Lambs in Wolves' Clothing, in ThE ECONOMICS OF TAXATION (Henry Aaron and M. Boskin eds. 1980).

${ }^{102}$ Iowa's single-factor sales formula was "long-standing" by the time the Supreme Court upheld its constitutionality in Moorman Manufacturing Co. v. Bair, 437 U.S. 267, 276 (1978). Nor was Iowa alone in its disproportionate weighting of the sales factor; five other states had over-weighted the state factor by the year Moorman was decided. Kirk J. Stark, The Quiet Revolution in U.S. Subnational Corporate Income Taxation, 2001 I.B.F.D. 523, 528 (2001).

${ }^{103}$ Charles E. McClure Jr. and Walter Hellerstein, Does Sales-Only Apportionment Violate International Trade Rules?, 96 TAX Notes 1513, 1514 (2002)

${ }^{104}$ See Bharat N. Anand and Richard Sansing, The Weighting Game: Formula Apportionment as an Instrument of Public Policy, 53 NAT’L TAX J. 183, 193 (2000).

${ }^{105}$ See Joann M. Weiner, supra note 74 , at 13.

${ }^{106} I d$. at $13-14$.
} 
Payments to independent contractors and other non-employee service providers are not taken into account in this factor.

\section{b. Property}

UDITPA measures the property factor by the average value of the taxpayer's real and tangible personal property, whether rented or owned. Rental property is valued at eight times its net annual rent, while owned property is valued at original cost plus the cost of additions and improvements. Depreciation is not allowed.

\section{c. Sales}

The sales factor includes all business income, whether from sales of goods, sales of services, rentals, royalties, or other unspecified business income. It is measured by gross receipts net of returns, allowances, and discounts. Sales of tangible property are treated as occurring in the state to which the goods are delivered or shipped. Income derived from other sorts of income producing transactions are assigned to the state in which the income-producing activity is performed, as demonstrated by the location of the costs of performing the activity. If an income-producing activity is performed in several states, UDITPA assigns the sales to the state in which the greatest costs of performance were incurred.

The operation of these state systems of formulary apportionment provides a case study of the perils that await those trying to impose a similar method of apportionment for income derived across national boundaries. Though some of the problems associated with the current, separate accounting based methods of allocating taxing jurisdiction are eliminated, some problems remain and new ones are created. How serious these problems are depends to a large extent on taxpayers' ability and willingness to forego some vertical integration of their activities.

\section{Operational Issues}

Whether a formulary method will work to solve-or even ameliorate-the current problems in the taxation of international transactions depends on two factors. The first is whether taxpayers can manipulate the factors contained in the formula to assign disproportionate amounts of income to low tax jurisdictions or jurisdictions which lack taxing power over them. The second is whether the base of the tax can be extended far enough, and completely enough, to keep taxpayers from placing undue amounts of their income beyond the reach of the formulary apportionment scheme. These two issues are related, both practically and thematically. At base, the question is whether formulary taxation will be significantly more effective than current, arm's length methods at stemming tax avoidance techniques. As the discussion below explains, neither the factors nor the tax base issues can be completely resolved; formulary taxation will never be a panacea. And unfortunately, many of the techniques taxpayers have developed to avoid tax under the current system can continue to be used to reduce taxation effected under a formulary method. The success (or lack thereof) of a formulary method in taxing international income will depend to a very large extent on patterns of trade and consumption, as well as the willingness of taxpayers to substitute contractual arrangements with unrelated parties for vertical integration through ownership. The U.S. experience with the subpart $F$ regime provides grounds for pessimism on both fronts. 
1. Factor Manipulation

Formulary taxation works only if and to the extent the factors used in the formula actually allocate income on an economically realistic basis. If they do not, if the factors can result in the allocation of income to jurisdictions in which taxpayers engage in relatively little business activity or derive little income, taxpayers will surely continue to locate income in low or no tax jurisdictions. Thus the question is, to what extent are the factors that have been used in formulary methods "real economic factors"-and to the extent they are not, can they be made "more economic"? These questions must be addressed on a factor by factor basis.

\section{a. The Payroll Factor}

In the U.S., the payroll factor is measured by the amounts reported as compensation to each state for state unemployment insurance purposes. As these amounts are determined under the Model Unemployment Compensation Act, the same metric is used by all states, and there is no reason to worry about state's use of inconsistent measures to distort the amounts allocated to them. ${ }^{107}$ Different countries, of course, have different definitions of compensation. In particular, they treat non-cash fringe benefits, which may amount to a substantial portion of salary, differently. These differences, if not adjusted, may lead to the systematic underrepresentation of some countries in the payroll factor.

More importantly, though, one has to worry about the failure to include payments to independent contractors and other non-employees in the payroll amount. In an era where "outsourcing" and "leasing" of employees is common, employers interested in reducing their tax burdens may selectively engage in such practices in high tax jurisdictions. This is far from a hypothetical worry. Currently, one technique for avoiding the reach of subpart $\mathrm{F}$ involves hiring a third party (call it Corp $\mathrm{X}$ ) to perform manufacturing services in a country A using the taxpayer's (call it Corp Y's) raw materials and intellectual property, including manufacturing know-how. Although the Corp X's income would be taxable in A, the country in which it conducted its activities, even if Corp Y were theoretically taxable in A, none of Corp Y's income would be apportioned to A under the payroll apportionment factor. Corp Y, after all, has no employees in A. It may derive a great deal of income from the manufacturing activity, however, by virtue of playing the role of financier, insurer of business risks, and, of course, provider of manufacturing know how and the like. But none of this income would be apportioned to A under the payroll factor. ${ }^{108}$ At least in the US, taxpayers have succeeded in finding “contract manufacturers” as these Corp X's are called, willing to play their roles for very small mark-ups over cost, leaving the Corp Y's with the lion's share of the resulting profits. Meanwhile, Corp Y's do not have to have a large staff to carry out their lucrative tasks, and can often locate that staff in a small tax haven country.

\footnotetext{
107 See1 JeROME R. HELlERSTEIN AND WALTER Hellerstein, supra note 75, ๆ 9.17, at 9-170-171.

${ }^{108}$ Nor would it be apportioned to A under property or sales factors, since Corp Y neither owns nor leases property in A (it is instead paying Corp $\mathrm{X}$ for the provision of a service) and derives no income from selling goods in A. Moreover, as described in more detail infra TAN 14-20, Corp Y probably lacks sufficient contacts with A for A to exercise taxing jurisdiction over any income apportioned to it.
} 
Interestingly, the definition of the property factor attempts to forestall analogous misbehavior by including a multiple of rental payments as the value of "leased" property. ${ }^{109}$ This may be much harder to do in the payroll context, however, if only because it is harder for all involved to be aware of, or keep track of, the instances and locations of all independent contractors. ${ }^{110}$ It would be hard to draft a rule that swept into the net amounts paid for "leased employees" and not legal fees paid to an outside law firm. ${ }^{111}$ Then again, perhaps no distinction should be made since a company has the option of maintaining an in-house legal department; its decision not to do so, or to maintain a smaller one, might be affected by tax considerations.

\section{b. Property}

There are two measurement issues that arise in connection with the property factor. One is the use of original cost, rather than depreciated cost or fair market value, as the basis of measurement. The other is the exclusion of intangible property.

The reason for using original cost is straightforward: it is easy and promotes uniformity across jurisdictions. It avoids the necessity of reconciling different depreciation systems across jurisdictions. And it avoids strategic misbehavior by both taxpayers and jurisdictions. The problem with using this figure is also straightforward: the original cost of an asset may bear little or no relationship to its current fair market value, which is surely the most economically relevant figure.

The absence of any allowance for depreciation results in the systematic overvaluation of older assets, thus decreasing the tax apportionable to jurisdictions in which new investments have been made. It is unclear how significant a problem this is, however. It is undoubtedly offset to some extent by a countervailing measurement failure, namely, the failure to adjust asset values for inflation. To the extent depreciation occurs in tandem with inflation, the original value (cost) of an asset may approximate its current fair market values. Whether this happy confluence of values occurs very often is unclear; it would require a committed optimist to believe that it is a regular occurrence. And, of course, inflation does not correct for changes in relative values.

Though the use of original value thus resembles nothing so much as the proverbial "looking under the streetlight because it is too dark to look elsewhere," it probably is too dark to look elsewhere. Not only would the determination of the fair market value of assets be a costly process, it may not lead to more accurate results because of taxpayer (or jurisdictional) misbehavior. Much business property does not

\footnotetext{
${ }^{109}$ See Joann Martens Weiner, supra note 77, at 21.

${ }^{110}$ It is unlikely, however, that even the expanded definition of rental payments includes the imputed rent portion of a payment for contract manufacturing services. To the extent it does not, taxpayers have a way to defeat the statutory attempt to include all rental property in the factor computation. This raises another issue: if the definition of payroll were expanded to include the cost of all subcontracted work, some portion of the cost would in fact be attributable to other factors such as property. Would accuracy be advanced by inclusion in the wrong factor instead of no factor at all? Of course, when a third party provides either buildings or employees, the third party should be earning (and paying tax) on the normal return for their use. At issue then is the location of the supernormal returns or rents derived from some combination of risk, business acumen, and intellectual property. When related parties are involved at both ends of the contract, even the normal return may be at issue.

${ }^{111}$ Canada includes "fees paid to another person for services that would normally be performed by employees of the corporation" in the payroll factor. Id. It would be interesting to know how successful its tax authorities are at making that distinction.
} 
trade on the open market on a regular basis. Just as is currently true of transfer prices, one would expect taxpayers to report uncertain valuations on the basis that would most benefit them.

Despite the inclusion of leased property in the property formula, outsourcing is a problem for this factor as well. Recall that under the contract manufacturing scenario described above, the independent contractor, Corp X, provided manufacturing facilities as well as manufacturing services. Yet, because the transaction would be structured as a service contract, the value of those facilities would not be included in the property formula. Perhaps that should not matter, since Corp X after all is taxed in A on the income it generates from its use of those facilities. As an independent third party, Corp X ought to be extracting the fair market value of that use from Corp Y through contract.

Corp Y's profit, in short, may not be derived from the use of the physical manufacturing property per se, but from other economic factors. Those factors are the product designs, manufacturing know how, branding and other forms of intellectual property used in the manufacture and eventual sale of the goods manufactured by Corp X.

The more serious distortion in the property formula comes from the fact that intangibles such as those listed above are generally excluded from the definition of property, even though (for accounting purposes) such intangibles account for approximately 70 percent of the value of the top 150 U.S. companies. ${ }^{112}$ Again, this exclusion too may not be as problematic as it first appears. First, intangible property is even harder to value than most physical assets. Thus including it in the apportionment formula might simply recreate the transfer pricing disputes that afflict separate accounting taxing systems in a slightly different guise. Moreover, even if intangible property could be valued, it is quite difficult to assign it to a particular location precisely because of its intangible nature. This makes its inclusion in the property factor an invitation for taxpayer manipulation. Indeed, for many (but not all) types of intangible income, particularly intellectual property rights such as patents, copyrights and marketing intangibles, one can make the case that the sales factor serves as a better proxy for income assignment purposes than the "location" of such property. ${ }^{113}$ After all, many of these intangibles ${ }^{114}$ generate value (whether through restraint of competition or through development of market demand) in the location where the product is consumed. If one is worried about distortions, the better move might be to increase the weight accorded to the sales factor to take into account that it is also serving at least part of the role of the property factor. Of course, that assumes that the sales factor looks to where the product or service is consumed. As the next paragraph makes clear, that is not always the case.

\section{c. Sales and Gross Receipts}

The sales factor sweeps in virtually all business receipts. Income from the sale of tangible property is allocated to the state in which is shipped or delivered, unless the taxpayer is not taxable in the state, in which case it is allocated to the state from which it

\footnotetext{
${ }^{112}$ Sebastian Mallaby, Powerful brand carries worth far beyond a familiar name, THE TIMES UNION, August 13, 2006, b-8.

${ }^{113}$ This is certainly true if the location of such assets would otherwise be determined by the residence of its owner.

${ }^{114}$ Unfortunately, this is not uniformly true. Process patents and other technological know-how relating to processes of production, would seem to generate value at least as much in the country where such production takes place as elsewhere.
} 
is shipped. ${ }^{115}$ Services income is allocated to the state in which the services are performed; if they are performed in several states, the income is assigned to the state where the greatest proportion of the income producing activity was performed.

The adoption of a delivery rule, rather than the "title passage" rule common to arm's length taxation systems, ${ }^{116}$ certainly is a move in the direction of economic reality. ${ }^{117}$ It is much more likely than the title passage rule to apportion income and thus tax revenues to the jurisdiction providing the market for the goods. Nonetheless, the delivery rule is far from foolproof because it does not in fact require taxpayers to trace goods to their ultimate destination. Taxpayers remain able to arrange for products destined for consumers in high tax jurisdictions to be sold and shipped to unrelated intermediaries located in low tax jurisdictions. Such sales would then be treated for tax purposes as having been made at the intermediary location. Some jurisdictions have tried to counter taxpayer efforts to avoid the intent of the delivery rule through the interposition of intermediate destinations by adopting an "ultimate-destination" or "ultimately received" test for attribution purposes. ${ }^{118}$ Both of these tests look to the place at which the goods end up after all transportation has been completed. Most jurisdictions, though, adopt the MTC position and require vendors to look only at the invoice address of its purchaser, to avoid introducing "time-consuming and burdensome complexities."119 These complexities may be substantial, particularly if the intermediary is an independent company. Such companies may be less than willing to divulge their customer lists and

\footnotetext{
115 See Joann Martens Weiner, supra note 77, at 22-23.

116 See Treas. Reg. $§ 1.861-7$ (c) ("a sale of personal property is consummated at the time when, and the place where, the rights, title, and interest of the seller in the property are transferred to the buyer"). The title passage rule is widely understood to favor taxpayers, because they have almost complete flexibility when choosing where along the path of shipment to pass title to goods. There is no necessary correlation between the use of the title passage rule and the maintenance (or not) of arm's length, separate entity accounting; indeed, at various points in time, commentators have suggested replacing the U.S. title passage rule with a more substantive rule such as a delivery rule. See AMERICAN LAW InSTITUTE, FEDERAL InCOME TAX Project, InTERnAtional AsPects of United STATES INCOME TAXATION, PROPOSALS ON United StATES TAXATION OF Foreign PERSONS AND OF THE FOREIGN INCOME OF UNITED STATES PERSONs 20-23 (1986) (discusses delivery rule, advocates place of sales activity test). To the extent the benefits of moving to a formulary system are attributable to replacing the title passage rule with a place of delivery rule, the only benefit provided by the formulary method per se is the camouflage it provides for this change in source rules.

${ }^{117}$ It certainly results in a more accurate determination of the economic source of income attributable to the monopoly power conferred by a market state’s protection of intellectual property rights. Whether a jurisdiction should be regarded as an economic source simply by virtue of having created conditions conducive to a market (regulation of the marketplace, sufficient protection of property rights and material wealth to create consumers) is perhaps more contestable.

118 See 1 Jerome R. Hellerstein AND WALTER HELLERSTEIN, supra note 75, ๆ 9.18[1][a] , at 9-185 - 9186.

${ }^{119}$ See id. at 9-185. Even in these jurisdictions, however, there is usually an exception for "drop shipments," where a manufacturer ships product directly to a retailer's customer at the retailer's request. In such situations, despite some inconsistency with the actual statutory language, most states consider the goods sold in the state to which they were shipped notwithstanding the fact that the actual "purchaser" (the retailer) is located elsewhere. See JEROME R. HELLERSTEIN AND WALTER HELLERSTEIN, supra note 87, at 667-669. Locating sales in a favorable jurisdiction entails some extra shipping and perhaps storage costs. Not all taxpayers are deterred by such costs, however, even when relatively low state taxes are at stake; since national tax rate differentials are higher, one would expect more taxpayers to take advantage of this tax minimization technique.
} 
other sales data to their supplier, which is what is required for operation of an ultimate destination or ultimate receipt test.

The problem with the rule for allocating services income is somewhat different. To a very large extent, the place of service test merely replicates the payroll factor ${ }^{120}$ and often results in little or no allocation to the market state. If the market state deserves some portion of the tax revenues in situations involving sales of tangible goods, the same concerns ought to justify a return from providing a market for services. ${ }^{121}$ The rule therefore should look at where the services generate benefits, a location that may be adduced by the location of the buyer, ${ }^{122}$ rather than where they were produced.

Determining this location, however, may be quite difficult. One could look to the address of the purchaser, but as is the case with tangible goods, there is no guarantee that the immediate purchaser is anything other than a middleman for some other, ultimate user. And the tracing problems may be more significant in the services context than in the tangible goods context. ${ }^{123}$ Indeed, a good example of the practical impediments to such determinations are the problems of determining the location of digital downloads of information or other content. Computers have a physical location, but vendors rarely know (or can check up) on them. Often, they have only a billing address, which may or may not correspond to their customer's business address. ${ }^{124}$

But there is an even more serious problem with any source rule that looks to the location of the purchaser. That problem is the jurisdictional problem: what if the taxpayer's only connection to the market jurisdiction is the customer? If the taxpayer is not otherwise engaged in business in the market jurisdiction-if it is a "remote seller"the market jurisdiction may have no jurisdiction to tax the seller. Apportioning income to the market jurisdiction then would be the equivalent of apportioning it to a no tax jurisdiction. States of the United States that have encountered this problem have come up with two disparate solutions: "throw out" and "throwback" rules. ${ }^{125}$ Under a "throw out"

\footnotetext{
${ }^{120}$ The version of the test utilized in UDIPTA is actually somewhat worse, as it attributes such sales to the place the service providers perform the most work. This "all-or-nothing approach" often produces "capricious and inequitable results" when services involve the expenditure of substantial amounts of time or costs in several different states. 1 JEROME R. HELlERSTEIN AND WALTER HELLERSTEIN, supra note 75, at 9-219.

${ }^{121}$ See id. at 9-220. The National Conference of Commissioners on Uniform State Laws recently announced the formation of a study group to review UDIPTA's rule for sourcing sales of services and intangibles. Dolores W. Gregory, Formulary Apportionment in a Service Economy: After 50 Years, Is UDIPTA in Need of an Overhaul?, 44 DAILY REPT. FOR EXECUTIVES (BNA) J-1 (March 7, 2007).

${ }^{122}$ This suggestion would be consistent with the rule found in the U.S.-India Double Tax Convention, which (contrary to general U.S. practice) allocates the primary right to tax income derived from the performance of technological and other specialized services based on the location of the buyer rather than the place of performance. However, unlike the situation covered by that treaty, some portion of the income would continue to be allocated to the performance state by virtue of the payroll factor.

${ }^{123}$ The classic quandary is where one sources a haircut performed in an airport barbershop: the location of the shop, the purchaser's residence, or where the purchaser happens to be traveling "for the useful life of the haircut"? See Dolores W. Gregory, supra note 121, at J-1. This problem is replicated in the sales of goods setting when someone buys a product while away from home or on the way out of town.

${ }^{124}$ See Dolores W. Gregory, supra note 121, at J-2 (discussing Illinois rule).

${ }^{125}$ Although the "throw back" rule is enshrined in UDIPTA, not all states have adopted it. See JEROME R. HELLERSTEIN AND WALTER HELLERSTEIN, supra note 87, at 667. The "throw out" rule was used in Pennsylvania until the Pennsylvania Supreme Court "held that the tax administrator lacked authority under Pennsylvania's version of UDIPTA to modify the state's apportionment provisions in this fashion.” Id.
} 
rule, factors existing in states without taxing jurisdiction are simply ignored in constructing both the numerator and denominator of the apportionment formula. ${ }^{126}$ So, for example, if ABC Corporation has \$100 million of sales, of which \$20 million are mail order sales to customers located in states in which ABC Corporation has no other physical or economic connection and hence no taxing jurisdiction, the states with taxing jurisdiction would treat ABC Corporation as having only $\$ 80$ million of sales for purposes of calculating their apportionable share of ABC Corporation's taxable income. Under the "throw back" rule, by contrast, the sales to customers in non-jurisdictional states would be treated as sales made to customers in the state of origin or sometimes commercial domicile. ${ }^{127}$ If ABC Corporation shipped $\$ 20$ million in goods from Delaware to Oregon, a state with no jurisdiction to tax ABC Corporation, Delaware's sales factor would amount to actual Delaware sales (say \$5 million) plus the $\$ 20$ million of Oregon sales; Delaware would thus be treated as having 25/100, or $1 / 4$ of all sales. Both of these mechanisms result in apportioning all corporate income to a state with the jurisdiction to tax it. ${ }^{128}$ However, under the throw out mechanism, the nonjurisdictional "taxes" are spread among all jurisdictional states in proportion to their share of the factor, while under the throw back mechanism, only the state of origin (or domicile) picks up additional revenue from the factors located in nonjurisdictional states.

Neither of these techniques works, though, if there are no jurisdictional states, that is, if none of the states operating the unitary, formulary taxing mechanism has jurisdiction to tax the income of ABC Corporation or its related entities. And as the next section points out, the path to avoiding jurisdiction — and apportioning income to those jurisdiction avoiding locales--is often less arduous than one would hope.

\section{Jurisdiction}

Jurisdictional issues and enforcement issues go hand in hand. The prevailing norm is that countries do not help other countries enforce their tax rules, except as specifically obliged under the terms of tax treaties_-and then, usually only grudgingly so. Thus, it has never made much sense for countries to assert taxing jurisdiction in situations where they lack leverage over the taxpayer or their income. Taxation based solely on source of income has always been particularly tenuous, given that the only method of collecting such a tax, withholding effected on gross income amounts, is a less than ideal taxing arrangement for business income. For this reason, most countries do not try to assert taxing jurisdiction over business income unless and until the taxpayer engages in substantial business activities within their borders or, if covered by a treaty, maintains a permanent establishment there. Restrictions on the taxing authority of states of the

\footnotetext{
126 See JEROME R. HELlERSTEIN AND WALTER HELLERSTEIN, supra note 87, at 667.

${ }^{127}$ Id. at 666-67.

${ }^{128}$ Under the throw out mechanism, $\$ 80$ million of $\$ 80$ million in recognized sales will be apportioned among the taxing states. Under the throw back mechanism, \$100 million in sales will be apportioned among states with taxing jurisdiction. Of course, the actual amount of tax collected from the taxpayer may be different than the amount that would have been taxed if all states in which sales took place had jurisdiction to tax the resulting income, since there is no guarantee that the states to which such income is reapportioned under these mechanisms levy tax at the same rate as the nonjurisdictional states would have levied tax had they been able to exercise taxing jurisdiction.
} 
United States come from the Constitution and federal legislation, and are less restrictive than the international norm. ${ }^{129}$

There are two aspects of the jurisdictional issue. One is the question of how much contact is required between a taxpayer and jurisdiction; the other is whether jurisdiction over one member of a group of related taxpayers confers jurisdiction over other members of the group. The second question, which is dealt with first in this article, relates to the issue of unitariness.

\section{a. Unitary vs. Single Entity}

As explained earlier, there is no necessary connection between formulary taxation and unitary taxation. Formulary accounting can be used to allocate the income of a single corporate (or noncorporate) taxpayer deriving income from multiple jurisdictions as easily (if not more easily) as the income from a group of related taxpayers. However, failing to extend formulary accounting to all the component parts of an even partially vertically integrated business enterprise invites abuse. A taxpayer can defeat the attempt to apportion income based on real economic factors by engaging in transactions with entities that fall outside the formulary base. Once the taxpayer has diverted large amounts of income to that outside entity through transfer price manipulation or careful location of intangible assets, there may be relatively little income left in the jurisdictional entity's income tax base for the formula to allocate. In the United States, for example, large corporations strip operating subsidiaries of profits by having them make deductible payments of interest or royalties to corporate entities created in low tax jurisdictions. Though some of the affected states have attempted to fight back by, for example, denying deductions for royalty payments made to related companies, ${ }^{130}$ such ad hoc remedies are far from complete solutions. Once one sort of payment becomes unavailable as a revenue-stripping device, taxpayers use another. For example, it will be interesting to see if state legislatures feel as comfortable denying deductions for the cost of goods sold by related companies as they are with denying deductions for royalties or interest. ${ }^{131}$

The successful operation of a formulary scheme thus requires that the formulary scheme reach all the actors in a vertically integrated enterprise, combining their income and factors for purposes of determining the amount of income earned from that enterprise in any particular jurisdiction. However, successful operation of such a unified formulary method involves coping with some difficult design issues.

The first of these issues is how to determine whether related entities are involved in an integrated, or unitary, business activity at all. Not surprisingly, taxpayers often litigate over whether their particular business activities are unitary in nature. Different states utilize different definitions of "unitary business." Some combine the income of all entities with sufficiently close ownership overlaps, while others look for a unity of ownership, operation and management, and still others for economic dependency,

\footnotetext{
${ }^{129}$ Whether that will remain true is open to question. Business groups have long sought a federal statute imposing a "uniform" jurisdictional standard that would condition taxation on the maintenance of a fairly significant amount of physical presence within the state. See Michael T. Fatale, Federalism and State Business Activity Tax Nexus: Revisiting Public Law, 21 VA. TAX Rev. 435, 500 \& fn. 350 (2002); Charles E. McLure Jr. and Walter Hellerstein, Congressional Intervention in State Taxation: A Normative Analysis of Three Proposals, 102 TAX NOTEs 1375, 1390 (2004).

${ }^{130}$ See Joann Martens-Weiner, supra note 6, at 83-84.

${ }^{131}$ Not all states are comfortable denying deductions even for interest and royalties expenses. See id.
} 
variously defined by flows of revenue or vertical integration. The outcomes of these cases are very fact dependent, and frequently contestable. The choice between the various definitions is essentially one of rules versus standards, of bright lines (such as ownership interests) or more diffuse concepts such as economies of scale. Like all rule/standard questions, there is no "correct" rule; the choice between the alternatives depends on the jurisdiction's relative tastes for economic accuracy and simplicity. ${ }^{132}$

The rules/standard dilemma extends not only to the choice of entities to subject to the formulary regime but also the income streams within those entities. In the real world, many multinational corporations engage not only in vertically integrated operations but also in operations that may be quite economically distinct and even locally based. This is of course also true in the multistate context; the classic (classroom) example is the corporation that operates both hotels and movie theaters. There is no particular reason to believe that the returns on the hotel business correspond to the returns on the movie theater business, and particularly if the hotel business is restricted to some jurisdictions while the movie theaters are found in others, apportioning the combined income among the jurisdictions based on a mathematical formula that does not distinguish between the two businesses may lead to anomalous results, at least, results that appear far from those that would result from the proper allocation of the arm's length method. At the same time, opportunities for taxpayer misbehavior-in the form of disguising profits from one business as profits from the other-exist in the absence of formulary taxation; at the very least, taxpayers may try to strategically allocate various forms of management and supervisory expenses, interest expenses and other general corporate expenses, as well as the income from investments and working capital. These opportunities exist whether the separate businesses are operated through separately incorporated entities or as branches of a single corporate entity. Again, the state experience ${ }^{133}$ shows that if lines must be drawn between different income streams earned within a corporate taxpayer, with some subject to formulary apportionment and others not (or being subject to a different formulary apportionment), conflict between taxpayers and governments will result. Full consolidation is easier though perhaps less economically accurate than allowing separate treatment of separate income streams from different lines of business. ${ }^{134}$

The simplest approach, from an implementation standpoint, would seem to be to force total consolidation of the income and factors of entities sharing more than a specified overlap of ownership interests. But forcing such consolidation may be far from easy because the further one extends the jurisdictional reach of a formulary system, the more significant the coordination problems become.

\section{b. The Coordination Problem}

\footnotetext{
${ }^{132}$ For an extended discussion of these issues, see I JEROME R. HELLERSTEIN AND WALTER HELLERSTEIN, supra note 75, ๆๆ 8.09-8.11.

${ }^{133}$ For constitutional reasons, states of the United States can only apportion the income stream of businesses connected to their state. They must separate out the income derived from movie theaters and the factors involved in producing that income when apportioning income in a jurisdiction outside the scope of that business. See id. at. 8-59. An explication of the disputes that have arisen in enforcing that rule can be found in id., at 8-62-8-213.

${ }^{134}$ Nor would it be entirely free of opportunities for taxpayers to engage in strategic behavior. See Joann M. Weiner, supra note 74 , at 29.
} 
Though it may be desirable to consolidate the income and factors of all related entities, discontinuities between the tax rules extant in the affected jurisdictions make such consolidation difficult and expensive. As a mechanical matter, determining the overall tax base and the value of the economic factors requires merging information derived from all the affected jurisdictions. If the information is collected using different definitions or standards, such mergers will require a country to accept considerable discontinuities in the data ${ }^{135}$ or require taxpayers to incur significant translation costs to get the data into the metric acceptable to that country. And, of course, if there are several different countries maintaining different formulary taxing systems, taxpayers could find themselves in the position of having to translate the world-wide accounts of their combined business operations into several different (or many different) metrics. Not only would this be extremely expensive, but the final result may be the under or over taxation of taxpayers due to differences between the definitional rules of the various affected countries. Even the most fervent supporters of formulary taxation believe that it will not work without substantially greater tax harmonization than currently exists.

Unfortunately, the institutional and political/economic barriers to effective coordination are substantial. As detailed in an earlier article, ${ }^{136}$ both national legislatures and many taxpayers are natural opponents of attempts to unify the definition of taxable income, though for different reasons. Legislatures would rightly see such unification as an attempt to strip them of authority to respond to localized political and economic imperatives with tax incentives or disincentives. Taxpayers would also see coordination as a threat to their ability to influence tax rules and to take advantage of current inconsistencies in those rules.

Moreover, coordination would be complex as an institutional matter. Coordination requires more than having the jurisdictions start out with the same rules; uniformity would have to be enforced with restrictions on future legislative action. Ideally, all statutory changes would have to be channeled through some multinational organization which would have the power to dictate rules for all participating countries. Further, coordination would have to exist at more than the level of statutory law. To prevent disparities in implementation, international institutions would have to be created to interpret statutory language, adjudicate contested situations, and perform the audit function. These institutions do not now exist, and their creation would come at some monetary and programmatic cost. ${ }^{137}$

\footnotetext{
${ }^{135}$ Multinational taxpayers use the discontinuities that currently exist to reduce their overall income tax liabilities, in a phenomenon inaccurately entitled "international tax arbitrage." See, e.g., Mitchell Kane, Strategy and Cooperation in National Responses to International Tax Arbitrage, 53 EMORY L. J. 89, 92 (2004); Diane M. Ring, One Nation Among Many: Policy Implications of Cross-Border Tax Arbitrage, 44 B. C. L. REv. 79, 80 (2002); Daniel Shaviro, Money on the Table?: Responding to Cross-Border Tax Arbitrage, 3 CHI. J. OF INT’L L. 317, 321 (2002).

${ }^{136}$ See Julie A. Roin, Taxation Without Coordination, 31 J. OF LEG. STUDIES S61 (2002).

${ }^{137}$ One question is whether the tax rules could be piggy-backed on top of the accounting rules, since the accounting profession is currently working towards a uniform set of internationally accepted standards. See Wolfgang Schon, The Odd Couple: A Common Future for Financial and Tax Accounting?, 58 TAx L. REv. 111, 114 (2005). Most large multinational corporations will have to adhere to this standard in order to be listed on desirable exchanges. See id. There is a large literature on the desirability (or not) of unifying tax and accounting rules, see, e.g., Linda M. Beale, Book-Tax Conformity and the Corporate Tax Shelter Debate: Assessing the Proposed Section 475 Mark-To-Market Safe Harbor, 24 VA. TAX REV. 301, 351 (2004); Michelle Hanlon, What Can We Infer About a Firm's Taxable Income From its Financial
} 
Of course, total uniformity is not necessary for formulary taxation. The tax statutes of the states of the United States differ in some respects. Few continue to adhere strictly to the federal definition of taxable income. Taxpayers seem able to cope with the discrepancies and make the adjustments necessary to the operation of a formulary system. However, it is easy to overstate the variation between the laws of the different states; in fact, few have wandered very far from the federal definition of taxable income, reducing the complexity of adjusting accounts determined under the laws of other states. The differences between national definitions of taxable income tend to be much more profound and harder to adjust. Indeed, it is for that precise reason that some of the proponents of the EU's move towards formulary taxation suggest that it be calculated on a "water's edge" basis, with only the income of entities incorporated in the EU apportioned on a formulary basis, and the income of related entities incorporated elsewhere continuing to be taxed on a separate entity, arm's length basis. ${ }^{138}$ The EU, perhaps even more than the federal government, has the institutional power to encourage adherence by its member states to uniform definitions of income and economic factors.

The problem with any water's edge system is that taxpayers can try to divert income to entities resident in low tax jurisdictions lying beyond that edge. ${ }^{139}$ Although one response might be to simply extend the reach of the formulary regime to related entities located in known tax haven jurisdictions--some countries have used "white lists" and "black lists" which categorize particular countries for tax purposes ${ }^{140}$--putting together such a list will be difficult. Defining a "low tax" jurisdiction is not all that easy. Often countries are low tax countries only in particular circumstances. For example, countries which operate territorial tax systems may be regarded as "tax havens" for

Statements?, 56 NAT'L TAX J. 831 (2003); Alvin D. Knott and Jacob D. Rosenfeld, Book and Tax: A Selective Exploration of Two Parallel Universes (pts. 1 \& 2), 99 TAX NoTES 865 (May 12, 2003), 99 TAX NotEs 1043 (May 19, 2003); Gil B. Manzon Jr. and George A. Plesko, The Relation Between Financial and Tax Reporting Measures of Income, 55 TAX L. REV. 175 (2002); Lillian F. Mills \& George A. Plesko, Bridging the Reporting Gap: A Proposal for More Informative Reconciling of Book and Tax Income, 56 NAT'L TAX J. 865 (2003); Alan B. Munro and Yoram Keinan, The Case for Book-Tax Conformity for Markto-Market Valuation, 16 J. TAX'N FIn. Inst. 5 (2003); Steven M. Rosenthal, Bank One, A Mark-to-Market Roadmap, 16 J. TAX'N Fin. INST. 18 (2003); Wolfgang Schon, supra; Wolfgang Schon, International Accounting Standards-A "Starting Point" for a Common European Tax Base?, 44 Eur. TAX'N 426 (2004); Sabine D. Selbach, The Harmonization of Corporate Taxation \& Accounting Standards in the European Community and their Interrelationship, 18 ConN. J.InT’L L. 523 (2003); Lee A. Sheppard, Financial Accounting Conformity: Not the Silver Bullet, 101 TAX Notes 676 (Nov. 10, 2003), and there is no sense in trying to recapitulate it here. I will simply note that the unification of the accounting rules is being undertaken by professional organizations, largely outside the political context, see Wolfgang Schon, supra , at 113 , so that deferring to accounting rules would further remove tax decisions from the political realm. Though that might (or might not) lead to better results overall, it surely will not be popular with those currently benefiting from governmental control of tax rules.

${ }^{138}$ The European Union Commission, for example, advocates formulary taxation of the EU profits of EU multinationals rather than a worldwide formulary approach. Commentators applaud this restraint. See, e.g., JoANn MARTENS-WeineR, supra note 6, at 35; Walter Hellerstein and Charles E. McClure Jr., supra note 6, at 206.

${ }^{139}$ They will also manipulate the factors to apportion income to low tax jurisdictions existing within the scope of the formulary regime, if there are any. It is worth noting that Ireland lies within the EU.

${ }^{140}$ Montana, the only U.S. state which tries to impose its corporate income tax on entities incorporated outside the U.S., limits the reach of its taxing regime to entities incorporated in a specified list of low tax countries. See Martin A. Sullivan, supra note 91, at 1024. The Dorgan bill, described supra note 120, also contains a list of 40 "notable" tax haven countries. 
income earned outside their borders, particularly if their source rules are easily manipulated, but given that most European nations operate territorial systems, ${ }^{141}$ it may be hard to justify adding a country to the list merely because it has a territorial system. Yet, for a taxpayer who earns large amounts of untaxed foreign source sales income, any territorial tax country constitutes a tax haven. This creates a second, political problem. How exactly will the disfavored countries (and therefore entities) be identified? Political considerations have been know to overcome tax considerations in determining the content of such lists, decreasing their usefulness as anti-abuse mechanisms.

Alternatively, countries might use some sort of "relative tax rate" test, similar to the one found in the current subpart F rules found in the Internal Revenue Code. That test looks to see whether the foreign tax imposed on covered income equals 90 percent of the what the U.S. tax would have been if the income had been earned domestically. ${ }^{142}$ Because different countries impose different tax rates on corporate income, this sort of rule would likely lead to some entities being included in the forced combination for some countries' tax purposes and not in others. ${ }^{143}$ How often this will occur, and the difficulties involved in "backing out" some entities from the combined tax base remains to be seen. Of course, the same problem would arise if countries adopted different "white" and "black" lists.

But the most serious problem with the inevitably "water's edge” nature of any formulary system is that some companies, and perhaps many companies, will be able to avoid having any members of their corporate group, or any portion of their income, subject to the formulary regime. They will do that by making sure that there are too few contacts between their operations and the members of the group of nations operating under the formulary system for jurisdiction to be established.

\section{c. Jurisdictional Issues}

Like countries, the states of the United States have the jurisdiction to impose an income tax based on both residence and source. Yet, apportionment of income to a jurisdiction under UDIPTA has never, in and of itself, been regarded as sufficient to confer taxing jurisdiction on a state. The U.S. Constitution ${ }^{144}$ has been interpreted to require a more substantial "nexus" requirement before allowing taxation of such income. Countries are not bound by these constitutional strictures of course; nonetheless, as a matter of statutory and treaty law, most refrain from taxing nonresident individuals and entities on most forms of business income unless and until the taxpayer's activities within the country are substantial enough to comprise a "trade or business" or (if a tax treaty

\footnotetext{
${ }^{141}$ And indeed, the formulary method will in most cases be operated in the context of a territorial regime.

${ }^{142}$ Note that the test would have to look at the amount of tax accrued with respect to the particular income item, rather than the general corporate income tax rate. A country with a high general tax rate and a territorial tax system would have a zero effective rate on foreign business income.

${ }^{143}$ In the case of the EU, Ireland would pose a particular problem. Would a country be considered a tax haven only if its rate was significantly lower than Ireland's - or would countries be free to set the definition of "low tax" with regard to their internal tax rates?

144 The constitutional limitations have been buttressed by Congressional action, such as the enactment in 1959 of Public Law 86-272, 73 Stat. 555 (1959), codified at 15 U.S.C. §£ 381-384. This statute prohibits states from imposing net income taxes on an interstate business whose business activities within the state are limited to soliciting orders for the sale of personal property, as long as those orders are accepted or rejected outside the state and the goods are shipped from outside the state.
} 
applies) the taxpayer has a "permanent establishment." To a large extent, these selfimposed restrictions reflect the practical reality that there is no good method of collecting net income taxes on the business income of nonresident taxpayers with minimal ties to the jurisdiction. A withholding tax based on gross income could be collected from domestic payors but such a tax could easily rise to extortionate levels, while the general norm against helping foreign countries enforce their income taxes would make enforcement of a tax on net income chancy at best. These problems do not disappear with a switch to formulary taxation. As a practical matter, it will still be difficult to obtain meaningful jurisdiction over business enterprises with minimal connections (other than income derived) from the U.S. And indeed, the most likely scenario is a continuation of the current regime, which requires the maintenance of a permanent establishment as a precondition for levying tax on the domestically sourced business income of a nonresident taxpayer.

Under the current system of separate entity, arm's length accounting, it is very simple for foreigners to keep most of their income outside a jurisdictional nexus based on these rules. All U.S. activities, for example, can be carried out through a U.S. subsidiary, while most income can be diverted to a related foreign corporation located in a tax haven country by careful manipulation of transfer prices or the ownership of assets or the location of business risks. ${ }^{145}$ Such a foreign entity's income cannot be reached directly by the U.S. taxing authorities unless the U.S. corporation can be denominated an "agent" of the foreign entity; only then would the U.S. entity's activities be imputed to the foreign company so that it would be deemed engaged in a U.S. trade or business. Tax treaties as well as U.S. statutes are quite specific in providing that mere commonality of ownership or vertical integration of the business enterprise is not enough to make the U.S. entity into an agent of the foreign entity. If the entities are diligent in the formalities, making sure that neither entity signs contracts in the name of the other and the like, the U.S. entity will generally be considered an "independent agent" rather than a “dependent agent," and thus will be prevented from imputing the U.S. entity's offices and trade and business activities to the foreign relative.

Moving from separate entity accounting to unitary accounting, forcing combined reporting on vertically integrated enterprises, would eliminate this easy escape. As long as the U.S. had jurisdiction over one entity, it would be allowed to combine the income

\footnotetext{
${ }^{145}$ The diversion of income from manufacturing operations and related know-how through the use of contract manufacturers was described supra TAN 54-57. Income can be diverted away from sales operations through the use of "commissionaire arrangements." Like contract manufacturing arrangements, commissionaire structures were developed to help taxpayers avoid the reach of subpart F. Rather than running their own retailing or wholesaling operations, foreign corporations set up subsidiaries to carry out such operations. As in the contract manufacturing scenario, the subsidiary's profit margin would be relatively small because the foreign parent would retain most of the business risk, either by retaining ownership of the inventory until immediately prior to sale or by maintaining a generous return policy. Further, the foreign corporation may contract directly with third parties to perform advertising and other selling-associated functions. As long as these third parties conform to the definition of independent agents, that is, as long as they formally act on behalf of their own trades or businesses rather than in the name of the foreign company, their actions and facilities are not imputed to the foreign corporation, which can continue to escape taxing jurisdiction in the sales state.. If the tax press can be believed, these structures are being successfully utilized by a number of taxpayers to avoid subpart F. See See Sandra P. McGill and Lowell D. Yoder, From Storefronts to Servers to Service Providers: Stretching the Permanent Establishment Definition to Accommodate New Business Models, 81 TAXES 141,153 (2003).
} 
and factors of all the related entities for purposes of determining the amount of tax owed. However, this would not mean that there would be no way to escape the U.S. (source) tax net, just that the escape is somewhat more complex.

At present, most companies use related entities to carry out their business operations in high tax jurisdictions; because of the treaty rules, they need not fear that one company's activities will be imputed to another, higher income, tax haven corporation. However, companies could substitute unrelated entities for related entities when carrying out operations in high tax-or formulary — states. Indeed, one of the original contract manufacturing cases, Ashland Oil, ${ }^{146}$ involved unrelated entities. The absence of an ownership relationship would make it much more difficult for countries to contend that a unitary business exists, and thus to reach the income of the low tax entity. The chain of vertical integration would be broken.

But would many multinational companies do this? Would they be willing to substitute contractual controls for ownership simply to enjoy lower tax liability? As tax scholars have recently pointed out, many tax obligations avoidable in theory are not in fact avoided. For example, governments still seem to collect at least some tax revenues attributable to gains from risky activities, despite the finance literature that suggests how taxpayers could and should avoid such taxes. ${ }^{147}$ The feasibility of avoidance techniques depends on the extent of what one scholar calls "frictions"148 and another calls "deadweight losses" or "inefficiencies"149 that must be endured in order to obtain the desired tax results. The tax savings must outweigh the costs of achieving them for real world taxpayers to be find tax minimizing schemes attractive.

The unanswered question is how many vertically integrated businesses will be willing to "deconstruct" in order to utilize commissionaire and contract manufacturing arrangements involving unrelated entities. Such deconstruction may raise institutional and labor issues, not to mention intellectual property and quality control issues, which make generalization of this technique impossible. But long ago, a very famous article about the nature of firms ${ }^{150}$ pointed out the interchangeability of contractual arrangements and vertical integration. The possibility of large scale avoidance of national income taxes may provide enough of a financial incentive to reverse prior decisions in favor of vertical integration. And indeed, the fact that at least some contract manufacturer and commissionaire arrangements currently use unrelated operating entities to perform some related services ${ }^{151}$ suggest that the transactions costs are not insuperable.

Over time, then, formulary taxation may do less to raise revenues than to reorganize multinationals as much smaller tax haven corporations holding large amounts

\footnotetext{
146 See supra note 57.

${ }^{147}$ See David Schizer, Balance In The Taxation of Derivative Securities: An Agenda for Reform, 104 Colum. L. REV. 1886, 1891 (2004).

148 See David Schizer, Frictions as a Constraint on Tax Planning, 101 Colum. L. REV. 1312, 1328 (2001).

149 David A. Weisbach, Line Drawing, Doctrine, and Efficiency in the Tax Law, 84 CORN. L. REV. 1627, 1661 (1999)

${ }^{150}$ See Ronald H. Coase, The Nature of the Firm, in THE NATURE OF THE FIRM: OrIGINS, EvOLUTION, AND DEVElOPMENT (Oliver E. Williamson \& Sidney G. Winter, eds. 1993), at 22 (explaining how levy of a sales tax might "bring into existence firms which otherwise would have no raison d'etre"). Taxation could have the exact opposite effect.

${ }^{151}$ See Sandra P. McGill and Lowell D. Yoder, supra note 145, at 150; Stephen Shay, Exploring Alternatives to Subpart F, 82 TAXES 29, 34 ("it is readily possible to avoid involvement of a related party as a principal in a transaction if necessary to achieve the desired objective”).
} 
of intellectual property and entering into elaborate contractual arrangements with unrelated companies owning physical business assets.

This jurisdictional problem is not, of course, unique to a unified, formulary system. It equally afflicts current arm's length, separate accounting taxing mechanisms. Thus, shifting to a formulary method will not make the problem worse. But the costs of shifting to a formulary system are substantial, and the scope of this problem suggests that the gains may not be.

\section{d. Options for Going Forward}

Is there any way out of this conundrum? Or is the income tax on a slow (or not so slow) march towards irrelevance? The question boils down to whether countries, particularly high tax countries, can effectively cast a wider jurisdictional net. They could do this in one of two ways. First, they could extend their ability to claim jurisdiction over business profits or proceeds on the basis of agency relationships. In particular, they could begin imputing corporate presence of foreign entities on the basis of business arrangements entered into with a broader range of domestic agents, including independent agents. Second, they could extend gross basis taxation of income derived by nonresident taxpayers, not only reversing the current trend towards diminution of such taxation but extending its scope to cover new sorts of proceeds. ${ }^{152}$ Neither of these options is foolproof or even particularly attractive, but ultimately the question is whether the alternative of nontaxation is worse.

The commissionaire and contract manufacturing structures eliminate taxation of the foreign entity because the current tax rules refuse to impute the existence of a "permanent establishment," the predicate for taxation of business profits, from the domestic presence of either an independent agent, or even a dependent agent that fails to conclude contracts in the name of the principal. These rules could be changed. At their most draconian, the rules could be amended to provide that any contractual arrangement with a domestic business enterprise would be treated as an agency relationship conferring permanent establishment based jurisdiction over the foreign corporation. However, exercising that jurisdiction would be difficult because of the absence of physical control over the foreign company. In the absence of much more extensive multilateral cooperation than currently exists, ${ }^{153}$ the country attempting to exercise jurisdiction would have to do so out of monies paid to the foreign company by the domestic agent/payor. When the domestic agent/payor is an unrelated company, it is highly unlikely that it would be in a position to calculate the foreign principal's tax on a net income basis; the tax thus would have to be withheld on the basis of gross income or gross sales proceeds. This gross basis tax could be a preliminary rather than a "final" tax obligation. That is, the foreign company could be allowed to submit a return after the fact, setting forth its tax obligation as calculated in accordance with regular tax rules, just as individual taxpayers are required to do in conjunction with employer withholding. However, the problems of auditing the foreign income, deductions and factors of a foreign company would remain. Or, to put it another way, the effect of imposing net income tax in such a situation would be the same as eliminating the purported "water's edge" nature of the

\footnotetext{
${ }^{152}$ Both of these changes would require revisions in current tax treaty arrangements.

${ }^{153}$ And there is no reason to believe such cooperation will be forthcoming in the future, as it will definitely be against the interests of the countries in which the foreign businesses are "resident."
} 
formulary system. If the proponents of formulary taxation are correct in their analysis that water's edge is necessary, net income taxation of these offshore corporations will not be possible, and only gross basis taxation would be a possibility.

The practical import of such a jurisdictional change would thus mimic the practical effects of the second option of imposing a source based withholding tax not only on the traditional forms of "passive" investment income (interest, rents and royalties) but also on business income such as sales and services income. ${ }^{154}$ The rate of this withholding tax would not, of course, have to match the current statutory withholding rates; if business income is assumed to have more significant associated expenses, a lower withholding tax rate might be appropriate.

But in the final analysis, a gross withholding tax is still a gross withholding tax, leaving open the possibility of either confiscatory or insufficient taxation, at least if a polity desires to levy a tax based on income. In fact, such a taxing system would look (and possibly operate) a great deal like the current border-adjusted value added tax systems. The result would be that internally produced and consumed goods and services would be subject to a net basis income tax, while imported goods and services would be subject to a gross basis value added tax.

Whether corporate taxpayers would prefer to pay the gross basis tax or the net basis tax would, undoubtedly, depend on both the relative tax rates and their particular circumstances. Since taxpayers control the corporate structure which will determine which of these taxes they will be subject to, they will undoubtedly elect into their preferred tax regime.

It is worth noting that all of these changes can be made as easily (which is not easily at all!) outside the context of a switch to formulary taxation as within it. In the final analysis, if countries are willing to make such changes, the choice between formulary and arm's length accounting may be relatively unimportant. The real problem with the current rules for the taxation of international transactions, in short, is less one of transfer pricing than of jurisdiction. If the jurisdictional flaws are solved, any taxing system will work (at least somewhat).

\section{Conclusion}

Although taxes are the price of civilization, most people and companies want the civilization without the taxes. Multinational corporations, in the view of many, have been all too successful at achieving this desired state. Formulary taxation has been touted as a mechanism for making sure that they pay their fair share. Unfortunately, even the best designed formulary system will be incapable of living up to its billing. Indeed, it

\footnotetext{
${ }^{154}$ As a technical matter, the latter approach would also require changes in the substance of source rules, to source income at the location of the purchaser of the goods and services rather than the location of the "sale of goods" or "place of performance" for services. A third method of arriving at almost the same place would be to deny domestic purchasers deductions for purchases from foreign countries. This would have the effect of inflating the purchasers' income by an amount corresponding to the amount escaping source country tax in the hands of the nonresident seller. Both states of the United States and foreign countries have (at various times) disallowed deductions for certain expenses paid to related "foreign" companies. The difference between these alternatives (withholding tax versus deduction loss) lies in rate differentials (the marginal tax rate of the purchaser versus a statutory withholding rate) and the possible availability of a tax credit on the seller's end (possible for a withholding tax, not for a lost deduction, since the tax would not be "levied" on the foreign taxpayer).
} 
remains open to question whether formulary taxation will be even a net improvement over the present arms' length pricing method based system (at least, outside the EU, in jurisdictions without an ECJ busy striking down antiabuse rules that keep separate accounting methods from collapsing). Unfortunately for governments, the adoption of formulary taxation will not even require the development of new avoidance methods, just an expansion of methods already employed by some of the very taxpayers against which the new taxing rules would be aimed. The solution to the problem of taxing income derived from international transactions, alas, may have to come from another direction altogether. And the solutions available from that direction are not particularly palatable. 
Readers with comments may address them to:

Professor Julie Roin

University of Chicago Law School

1111 East 60th Street

Chicago, IL 60637 julie_roin@law.uchicago.edu 


\section{The University of Chicago Law School Public Law and Legal Theory Working Paper Series}

1. $\quad$ Cass R. Sunstein and Edna Ullmann-Margalit, Second-Order Decisions (November 1999; Ethics, v.110, no. 1)

2. Joseph Isenbergh, Impeachment and Presidential Immunity from Judicial Process (November 1999; forthcoming Yale Law and Policy Review v.18 \#1).

3. Cass R. Sunstein, Is the Clean Air Act Unconstitutional? (August 1999; Michigan Law Review \#3).

4. Elizabeth Garrett, The Law and Economics of "Informed Voter" Ballot Notations (November 1999, University of Virginia Law Review, v. 85).

5. David A. Strauss, Do Constitutional Amendments Matter? (November 1999)

6. Cass R. Sunstein, Standing for Animals (November 1999)

7. Cass R. Sunstein, Culture and Government Money: A Guide for the Perplexed (April 2000).

8. Emily Buss, Without Peers? The Blind Spot in the Debate over How to Allocate Educational Control between Parent and State (April 2000).

9. David A. Strauss, Common Law, Common Ground, and Jefferson's Principle (June 2000).

10. Curtis A. Bradley and Jack L. Goldsmith, Treaties, Human Rights, and Conditional Consent (May 2000; Pennsylvania Law Review v. 149).

11. Mary Ann Case, Lessons for the Future of Affirmative Action from the Past of the Religion Clauses? (May 2001, Supreme Court Review, 2000)

12. Cass R. Sunstein, Social and Economic Rights? Lessons from South Africa (May, 2000).

13. Jill Elaine Hasday, Parenthood Divided: A Legal History of the Bifurcated Law of Parental Relations (June 2001)

14. Elizabeth Garrett, Institutional Lessons from the 2000 Presidential Election (May 2001).

15. Richard A. Epstein, The Allocation of the Commons: Parking and Stopping on the Commons (August 2001).

16. Jack Goldsmith, The Internet and the Legitimacy of Remote Cross-Border Searches (October 2001).

17. Adrian Vermeule, Does Commerce Clause Review Have Perverse Effects? (October 2001).

18. Cass R. Sunstein, Of Artificial Intelligence and Legal Reasoning (November 2001).

19. Elizabeth Garrett, The Future of Campaign Finance Reform Laws in the Courts and in Congress, The William J. Brennan Lecture in Constitutional Law (December 2001).

20. Julie Roin, Taxation without Coordination (March 2002).

21. Geoffrey R. Stone, Above the Law: Research Methods, Ethics, and the Law of Privilege (March 2002; forthcoming J. Sociological Methodology 2002).

22. Cass R. Sunstein, Is There a Constitutional Right to Clone? (March 2002).

23. Emily Buss, Parental Rights (May 2002, forthcoming Virginia Law Review).

24. David A. Strauss, Must Like Cases Be Treated Alike? (May 2002).

25. David A. Strauss, The Common Law Genius of the Warren Court (May 2002).

26. Jack Goldsmith and Ryan Goodman, U.S. Civil Litigation and International Terrorism (June 2002).

27. Jack Goldsmith and Cass R. Sunstein, Military Tribunals and Legal Culture: What a Difference Sixty Years Makes (June 2002).

28. Cass R. Sunstein and Adrian Vermeule, Interpretation and Institutions (July 2002).

29. Elizabeth Garrett, Is the Party Over? The Court and the Political Process (August 2002).

30. Cass R. Sunstein, The Rights of Animals: A Very Short Primer (August 2002).

31. Joseph Isenbergh, Activists Vote Twice (November 2002).

32. Julie Roin, Truth in Government: Beyond the Tax Expenditure Budget (November 2002).

33. Cass R. Sunstein, Hazardous Heuristics (November 2002). 
34. Cass R. Sunstein, Conformity and Dissent (November 2002).

35. Jill Elaine Hasday, The Principle and Practice of Women's "Full Citizenship": A Case Study of Sex-Segregated Public Education (December 2002).

36. Cass R. Sunstein, Why Does the American Constitution Lack Social and Economic Guarantees? (January 2003).

37. Adrian Vermeule, Mead in the Trenches (January 2003).

38. Cass R. Sunstein, Beyond the Precautionary Principle (January 2003).

39. Adrian Vermeule, The Constitutional Law of Congressional Procedure (February 2003).

40. Eric A. Posner and Adrian Vermeule, Transitional Justice as Ordinary Justice (March 2003).

41. Emily Buss, Children's Associational Rights? Why Less Is More (March 2003)

42. Emily Buss, The Speech Enhancing Effect of Internet Regulation (March 2003)

43. Cass R. Sunstein and Richard H. Thaler, Libertarian Paternalism Is Not an Oxymoron (May 2003)

44. Elizabeth Garrett, Legislating Chevron (April 2003)

45. Eric A. Posner, Transfer Regulations and Cost-Effectiveness Analysis (April 2003)

46. Mary Ann Case, Developing a Taste for Not Being Discriminated Against (May 2003)

47. Saul Levmore and Kyle Logue, Insuring against Terrorism—and Crime (June 2003)

48. Eric Posner and Adrian Vermeule, Accommodating Emergencies (September 2003)

49. Adrian Vermeule, The Judiciary Is a They, Not an It: Two Fallacies of Interpretive Theory (September 2003)

50. Cass R. Sunstein, Ideological Voting on Federal Courts of Appeals: A Preliminary Investigation (September 2003)

51. Bernard E. Harcourt, Rethinking Racial Profiling: A Critique of the Economics, Civil Liberties, and Constitutional Literature, and of Criminal Profiling More Generally (November 2003)

52. Jenia Iontcheva, Nationalizing International Criminal Law: The International Criminal Court As a Roving Mixed Court (January 2004)

53. Lior Jacob Strahilevitz, The Right to Destroy (January 2004)

54. Adrian Vermeule, Submajority Rules (in Legislatures and Elsewhere) (January 2004)

55. Jide Nzelibe, The Credibility Imperative: The Political Dynamics of Retaliation in the World Trade Organization's Dispute Resolution Mechanism (January 2004)

56. Catharine A. MacKinnon, Directions in Sexual Harassment Law: Afterword (January 2004)

57. $\quad$ Cass R. Sunstein, Black on Brown (February 2004)

58. Elizabeth F. Emens, Monogamy’s Law: Compulsory Monogamy and Polyamorous Existence (February 2004)

59. Bernard E. Harcourt, You Are Entering a Gay- and Lesbian-Free Zone: On the Radical Dissents of Justice Scalia and Other (Post-) Queers (February 2004)

60. Adrian Vermeule, Selection Effects in Constitutional Law (March 2004)

61. Derek Jinks and David Sloss, Is the President Bound by the Geneva Conventions? (July 2004)

62. Derek Jinks and Ryan Goodman, How to Influence States: Socialization and International Human Rights Law (March 2004)

63. Eric A. Posner and Alan O. Sykes, Optimal War and Jus Ad Bellum (April 2004)

64. Derek Jinks, Protective Parity and the Law of War (April 2004)

65. Derek Jinks, The Declining Significance of POW Status (April 2004)

66. Bernard E. Harcourt, Unconstitutional Police Searches and Collective Responsibility (June 2004)

67. Bernard E. Harcourt, On Gun Registration, the NRA, Adolf Hitler, and Nazi Gun Laws: Exploding the Gun Culture Wars \{A Call to Historians\} (June 2004) 
68. Jide Nzelibe, The Uniqueness of Foreign Affairs (July 2004)

69. Derek Jinks, Disaggregating "War” (July 2004)

70. Jill Elaine Hasday, Mitigation and the Americans with Disabilities Act (August 2004)

71. Eric A. Posner and Cass R. Sunstein, Dollars and Death (August 2004)

72. Cass R. Sunstein, Group Judgments: Deliberation, Statistical Means, and Information Markets (August 2004)

73. Adrian Vermeule, Constitutional Amendments and the Constitutional Common Law (September 2004)

74. Elizabeth Emens, The Sympathetic Discriminator: Mental Illness and the ADA (September 2004)

75. Adrian Vermeule, Three Strategies of Interpretation (October 2004)

76. $\quad$ Cass R. Sunstein, The Right to Marry (October 2004)

77. Jill Elaine Hasday, The Canon of Family Law (October 2004)

78. Adam M. Samaha, Litigant Sensitivity in First Amendment Law (November 2004)

79. Lior Jacob Strahilevitz, A Social Networks Theory of Privacy (December 2004)

80. Cass R. Sunstein, Minimalism at War (December 2004)

81. Eric A. Posner, The Decline of the International Court of Justice (December 2004)

82. Tim Wu, The Breach Theory of Treaty Enforcement (February 2005, revised March 2005)

83. Adrian Vermeule, Libertarian Panics (February 2005)

84. Eric A. Posner and Adrian Vermeule, Should Coercive Interrogation Be Legal? (March 2005)

85. Cass R. Sunstein and Adrian Vermeule, Is Capital Punishment Morally Required? The Relevance of Life-Life Tradeoffs (March 2005)

86. Adam B. Cox, Partisan Gerrymandering and Disaggregated Redistricting (April 2005)

87. Eric A. Posner, Political Trials in Domestic and International Law (April 2005)

88. Cass R. Sunstein, Irreversible and Catastrophic (April 2005)

89. Adam B. Cox, Partisan Fairness and Redistricting Politics (April 2005, NYU L. Rev. 70, \#3)

90. Cass R. Sunstein, Administrative Law Goes to War (May 2005, Harvard L. Rev., forthcoming)

91. Cass R. Sunstein, Chevron Step Zero (May 2005)

92. Bernard E. Harcourt, Policing L.A.'s Skid Row: Crime and Real Estate Development in Downtown Los Angeles [An Experiment in Real Time] (May 2005)

93. Bernard E. Harcourt and Jens Ludwig, Broken Windows: New Evidence from New York City and a Five-City Social Experiment (May 2005)

94. Bernard E. Harcourt, Against Prediction: Sentencing, Policing, and Punishing in an Actuarial Age (May 2005)

95. Philip Hamburger, The New Censorship: Institutional Review Boards (May 2005)

96. Eugene Kontorovich, Disrespecting the "Opinions of Mankind” (June 2005)

97. Tim Wu, Intellectual Property, Innovation, and Decision Architectures (June 2005)

98. Lior Jacob Strahilevitz, Exclusionary Amenities in Residential Commons (July 2005)

99. Cass R. Sunstein, Ranking Law Schools: A Market Test? (July 2005)

100. Mary Anne Case, Pets or Meat (August 2005)

101. Adam Samaha, Executive Exposure: Government Secrets, Constitutional Law, and Platforms for Judicial Intervention (August 2005, revised November 2005)

102. Jason J. Czarnezki and William K. Ford, The Phantom Philosophy? An Empirical Investigation of Legal Interpretation (August 2005)

103. Adrian Vermeule, Absolute Voting Rules (August 2005)

104. Eric A. Posner and Adrian Vermeule, Emergencies and Democratic Failure (August 2005)

105. Adrian Vermeule, Reparations as Rough Justice (September 2005) 
106. Arthur J. Jacobson and John P. McCormick, The Business of Business Is Democracy (September 2005)

107. Tracey Meares and Kelsi Brown Corkran, When 2 or 3 Come Together (October 2005)

108. Adrian Vermeule, Political Constraints on Supreme Court Reform (October 2005)

109. Lior Jacob Strahilevitz, Information Asymmetries and the Rights to Exclude (November 2005)

110. Cass R. Sunstein, Fast, Frugal and (Sometimes) Wrong (November 2005)

111. Cass R. Sunstein, Justice Breyer's Democratic Pragmatism (November 2005)

112. Adam M. Samaha, Endorsement Retires: From Religious Symbols to Anti-Sorting Principles (November 2005)

113. Adam M. Samaha, Undue Process: Congressional Referral and Judicial Resistance in the Schiavo Controversy (November 2005)

114. Bernard E. Harcourt, Should We Aggregate Mental Hospitalization and Prison Population Rates in Empirical Research on the Relationship between Incarceration and Crime, Unemployment, Poverty, and Other Social Indicators? On the Continuity of Spatial Exclusion and Confinement in Twentieth Century United States (January 2006)

115. Elizabeth Garrett and Adrian Vermeule, Transparency in the Budget Process (January 2006)

116. Cass R. Sunstein, Burkean Minimalism (January 2006)

117. Stephanos Bibas, Transparency and Participation in Criminal Procedure (February 2006)

118. Douglas G. Lichtman, Captive Audiences and the First Amendment (February 2006)

119. Eric A. Posner and Cass R. Sunstein, The Law of Other States (March 2006)

120. Jeff Leslie and Cass R. Sunstein, Animal Rights without Controversy (March 2006)

121. Adrian Vermeule, The Delegation Lottery (March 2006)

122. Adrian Vermeule, Self-Defeating Proposals: Ackerman on Emergency Powers (March 2006)

123. Bernard E. Harcourt, Muslim Profiles Post 9/11: Is Racial Profiling an Effective Counterterrorist Measure and Does It Violate the Right to Be Free from Discrimination? (March 2006)

124. Christine Jolls and Cass R. Sunstein, The Law of Implicit Bias (April 2006)

125. Lior Strahilevitz, “How's My Driving?” for Everyone (and Everything?) (April 2006)

126. Jack Goldsmith and Eric A. Posner, The New International Law Scholarship (May 2006)

127. Eric A. Posner and John Yoo, International Law and the Rise of China (May 2006)

128. Eric A. Posner and Cass R. Sunstein, Chevronizing Foreign Relations Law (May 2006)

129. Jacob E. Gersen and Adrian Vermeule, Chevron as a Voting Rule (June 2006)

130. Jacob E. Gersen, Temporary Legislation (June 2006)

131. Adam B. Cox, Designing Redistricting Institutions (June 2006)

132. Adam B. Cox, The Temporal Dimension of Voting Rights (July 2006)

133. Curtis A. Bradley and Eric A. Posner, Presidential Signing Statements and Executive Power (July 2006)

134. Cass R. Sunstein, Clear Statement Principles and National Security: Hamdan and Beyond (July 2006)

135. Cass R. Sunstein, Of Snakes and Butterflies: A Reply (August 2006)

136. Cass R. Sunstein, Montreal versus Kyoto: A Tale of Two Protocols (September 2006)

137. Douglas Lichtman, Irreparable Benefits (September 2006)

138. Adam M. Samaha, Undue Process (September 2006)

139. Eric A. Posner and Adrian Vermeule, The Credible Executive (September 2006)

140. Adam B. Cox and Eric A. Posner, The Second-Order Structure of Immigration Law (November 2006)

141. Eric A. Posner, The International Protection of Cultural Property: Some Skeptical Observations (November 2006) 
142. Bernard E. Harcourt and Jens Ludwig, Reefer Madness: Broken Windows Policing and Misdemeanor Marijuana Arrests in New York City, 1989-2000 (December 2006)

143. Bernard E. Harcourt, Embracing Chance: Post-Modern Meditations on Punishment (December 2006)

144. Cass R. Sunstein, Second-Order Perfectionism (December 2006)

145. Wayne Hsiung and Cass R. Sunstein, Climate Change and Animals (January 2007)

146. Cass R. Sunstein, Deliberating Groups versus Prediction Markets (or Hayek’s Challenge to Habermas) (January 2007)

147. Cass R. Sunstein, Incompletely Theorized Agreements in Constitutional Law (January 2007)

148. Eric A. Posner, Climate Change and Human Rights Litigation: A Critical Appraisal (January 2007)

149. Cass R. Sunstein, Cost-Benefit Analysis without Analyzing Costs or Benefits: Reasonable Accommodation, Balancing,a nd Stigmatic Harms (January 2007)

150. Cass R. Sunstein, Willingness to Pay versus Welfare (January 2007)

151. Cass R. Sunstein, If People Would Be Outraged by Their Rulings, Should Judges Care? (February 2007)

152. Bernard E. Harcourt, Judge Richard Posner on Civil Liberties: Pragmatic Authoritarian Libertarian (March 2007)

153. Eugene Kontorovich, What Standing Is Good For (March 2007)

154. Eugene Kontorovich, Inefficient Customs in International Law (March 2007)

155. Bernard E. Harcourt, From the Asylum to the Prison: Rethinking the Incarceration Revolution. Part II: State Level Analysis (March 2007)

156. Bernard E. Harcourt, An Answer to the Question: "What Is Poststructuralism?” (March 2007)

157. Cass R. Sunstein, Backlash’s Travels (March 2007)

158. Cass R. Sunstein, Due Process Traditionalism (March 2007)

159. Adam B. Cox and Thomas J. Miles, Judging the Voting Rights Act (March 2007)

160. Jonathan F. Mitchell, Apprendi’s Domain (April 2007)

161. Jacob E. Gersen, Overlapping and Underlapping Jurisdiction in Administrative Law (April 2007)

162. Eric A. Posner and Cass R. Sunstein, On Learning from Others (April 2007)

163. Eric A. Posner and Adrian Vermeule, Originalism and Emergencies: A Reply to Lawson (April 2007)

164. Cass R. Sunstein, Illusory Losses (April 2007)

165. Josh Bowers, Punishing the Innocent (April 2007)

166. Adam M. Samaha, What Good Is the Social Model of Disability? (May 2007)

167. Cass R. Sunstein, On the Tension between Sex Equality and Religious Freedom (June 2007)

168. Jacob E. Gersen, Legislative Rules Revisited (June 2007)

169. Josh Bowers, Grassroots Plea Bargaining (June 2007)

170. Julie Roion, Can the Income Tax Be Saved? The Promise and Pitfalls of Unitary Formulary Apportionment (April 2007) 